\title{
42. Türkçe öğretmenlerinin 21. yüzyılda sahip olması gereken yeterlilikler ${ }^{1}$
}

\section{Yasemin BAKं'²}

APA: Baki, Y. (2021). Türkçe öğretmenlerinin 21. yüzyılda sahip olması gereken yeterlilikler. RumeliDE Dil ve Edebiyat Araştırmaları Dergisi, (23), 660-684. DOI: 10.2900o/rumelide.949533.

\section{$\ddot{\mathbf{O} z}$}

Bu araştırmada Türkçe öğretmenlerinin 21. yüzyılda sahip olması gereken temel yeterliliklerin, öğretmen adaylarının bakış açısıyla değerlendirilmesi amaçlanmıştır. Nitel araştırma yönteminin, durum çalışması deseniyle gerçekleştirilen araştırmanın çalışma grubunun belirlenmesinde amaçlı örnekleme yöntemlerinden kolay ulaşılabilir durum örneklemesi kullanılmıştır. Bu örnekleme yoluyla belirlenmiş olan katılımcılar, 2018 akademik yılının bahar döneminde Recep Tayyip Erdoğan Üniversitesi Türkçe Öğretmenliği Bölümü 3. sınıfta öğrenim gören 34 öğretmen adayından oluşmaktadır. Araştırmada veriler, iki açı uçlu sorudan oluşan yarı yapılandırılmış görüşme formu aracılı̆̆ıyla toplanmış ve görüşmeler 30 dakika sürmüştür. Araştırmadan elde edilen veriler içerik analiziyle değerlendirilmiştir. Araştırma sonucunda Türkçe öğretmenlerinin 21. yüzyılda sahip olması gereken yeterlilikler; temel yeterlilikler ve temel değerler olarak iki ana tema altında toplanmıştır. Temel yeterlilikler ise kişisel yeterlilikler ve özel alan yeterlilikleri olmak üzere iki alt temaya ayrılmıştır. Araştırma sonucunda Türkçe öğretmenlerinin sahip olması gereken kişisel yeterliliklerde yaratıcılık ve yenilikçilik; özel alan yeterliliklerinde ise Türkçeyi etkin bir şekilde kullanabilme, sınıf içinde etkili iletişim kurabilme, işbirlikçi ve disiplinler arası bakış açısıyla örülü bir öğrenme ortamı oluşturabilme yeterlilikleri ön plana çıkmaktadır. Ayrıca Türkçe öğretmenlerinin çağın teknolojik okuryazarlık becerilerine sahip olmaları ve bu becerileri Türkçe dersine uyarlayabilmeleri en sık tekrarlanan yeterlilikler arasındadır. Türkçe öğretmeninin sahip olması gereken temel değerlere ilişkin sonuçlar incelendiğinde ise sevgi, saygı ve vatanseverlik değerlerinin ön plana çıkmaktadır. Bu sonuçlardan hareketle; evrensel değerlere erişmiş, yaratıcı ve yenilikçi bir Türkçe öğretmeni profilinin ortaya konulduğu söylenebilir.

Anahtar kelimeler: 21. yüzyll, Türkçe öğretmenleri, yeterlilik, değer

\section{Competencies that Turkish teachers need to have in the 21st century}

\begin{abstract}
This study aims to evaluate the basic competencies that Turkish teachers should have in the 21st century from the perspective of pre-service teachers. The study was conducted with the case study design of the qualitative research methods. The readily available convenience sampling, which is one of the purposeful sampling methods was used to determine the study group. Participants determined through this sampling consist of 34 pre-service teachers studying their third years at Turkish Language Teaching Department of Recep Tayyip Erdogan University in the spring semester of the 2018 academic year. The data were collected through a semi-structured interview form consisting of two open-ended questions in the study, and the interviews lasted 30 minutes. The data
\end{abstract}

Bu araştırma 27-29 Ekim 2018 tarihinde gerçekleştirilen II. International Teacher Education and Accreditation Congress'te sözlü bildiri olarak sunulmuş çalışmanın genişletilmiş şeklidir.

Doç. Dr., Recep Tayyip Erdoğan Üniversitesi, Eğitim Fakültesi, Türkçe ve Sosyal Bilimler Eğitimi Bölümü, Türkçe Eğitimi ABD (Rize, Türkiye), ysmnbaki@gmail.com, oooo 000340643724 [Araştırma makalesi, Makale kayıt tarihi: 21.03.2021-kabul tarihi: 20.06.2021; DOI: 10.29000/rumelide.949533]

Adres Address

RumeliDE Dil ve Edebiyat Araşttrmaları Dergisi $\quad$ RumeliDE Journal of Language and Literature Studies Osmanağa Mahallesi, Mürver Çiçeği Sokak, No:14/8 Osmanağa Mahallesi, Mürver Çiçeği Sokak, No:14/8

Kadıköy - İSTANBUL / TÜRKIYE 34714 Kadıköy - ISTANBUL / TURKEY 34714 e-posta: editor@rumelide.com

e-mail: editor@rumelide.com

tel: +90 505 7958124, +90 2167730616 phone: +90 505 7958124, +90 2167730616 
obtained from the research were evaluated by content analysis. As a result of the study, the competencies that Turkish teachers should have in the 21st century were grouped under two main themes as basic competencies and basic values. Basic competencies are divided into two subthemes: personal competences and special field competencies. As a result of the study, creativity and innovativeness were highlighted in the personal competencies that Turkish teachers should have, while the ability to use Turkish effectively, to communicate effectively in the classroom, to create a learning environment with a collaborative and interdisciplinary perspective come to the forefront in the special field competencies. Additionally, the most frequently repeated competencies were Turkish language teachers' having the technological literacy skills of the age and their being able to adapt these skills to the Turkish courses. When the results regarding the basic values that a Turkish teacher should have were examined; the values of love, respect and patriotism came to the fore. With reference to these results; It can be said that the Turkish teacher profile who is creative and innovative and has universal values has been revealed.

Keywords: 21st century, Turkish teachers, competency, value

\section{Giriş}

Bilgi edinme insanın var olduğu andan başlayıp sonsuza kadar sürecek en başat kabiliyetlerinden biridir. Bu süreç bireyin kendi özüne dönüşü ve kendindeki gerçekliğin farkına varışıdır. İnsan sonsuza uzanan eşsiz bir varlık olması sebebiyle bu sonsuzluğu da ancak bildiği oranda algılayıp yaşayabilecektir. $\mathrm{Bu}$ serüvende insanın en önemli yakıtı olan bilgi, insanlığın kendini keşfedişi oranında değişmekte ve yenilemektedir. Bu yüzyılın da ana belirleyici kavramı bilgi, ana dönüştürücü kavramı da değişim olup bilgi doğası gereği sürekli bir değişim ve yenilenme halindedir. Bu yenilenme sürecinde değişmeyen tek şey ise değişimin kendisidir. Değişimdeki bu dinamikliğin farkına varmış bireyler buna ayak uydurabilmek için mevcut yenilikleri takip etmekte, gerektiğinde de bu yeniliklerin öncüleri olmaktadırlar. Bu yeniliklerin açığa çıkışı da devrin düşünce araçlarına göre değişmektedir.

Sanayi toplumundan bilgi toplumuna geçişin yaşandığı bu yüzyıldaki düşme becerilerindeki değişiklikle sanayideki makinenin yerini bilgisayar, insanın çalışma gücünün yerini ise bilgi almıştır (Özden, 2002). Bu değişim 200o'li yılların başında sanayileşme sürecini tamamlayan toplumların sonraki dönem olan "bilgi toplumu" evresine geçişiyle başlamıştır (Sarıgöz, 2012'den aktaran Öztekin, 2020). İnsanın varlığı algılayışına ilişkin düşünce düzeyinde meydana gelen paradigma değişimi kullanılan yöntemlerin ve araçların da dönüşümünü beraberinde getirmiştir. Nitekim bu dönüşüm teknoloji noktasında kendini göstermiş, bilginin elde edilişi ve kullanılışında teknoloji ile kendini göstermiştir. Teknolojideki hızl gelişmelerle de adeta bir bilgi devrimi yaşanmış ve bilgi teknolojileri olarak bu devirde hayat bulmuştur (Niess, 2005; Öztekin, 2020). Günümüzde daha hızlı ve belirgin bir şekilde kendini gösteren bilgi teknolojilerindeki çeşitli yenilikler bu sürecin hızlanmasında önemli bir yere sahiptir. Bu yenilikler her sahada köklü değişiklikler meydan getirmekle birlikte nitelikli insan gücünün yetişmesini sağlayan eğitim boyutunda da pek çok yeniliği beraberinde getirmiştir.

Eğitimdeki bu değişimin ana kaynağı ise bilginin doğasına ilişkin yaşanan anlayış değişiklidir. Sanayi toplumunda, pozitivist bilim geleneği içinde bilgi "mutlak ve kesin bir doğru” olarak değerlendirilirken bu anlayış bilgi toplumunda, bilimsel doğru ve yargıların mutlak olmadığı fikrine evrilmiştir. Bu değişikliğin eğitimdeki yansımasıyla öğrencinin bilgiyle yüklenmesi anlayışından vazgeçilmiş bunun yerine bilgi üretme kapasitesinin artırılmasına dönük çalışmalara geçilmiştir (Gültekin, 2020). Bilginin doğasına ilişkin bu anlayış değişikliğinin yanı sıra teknolojideki gelişmelere paralel olarak

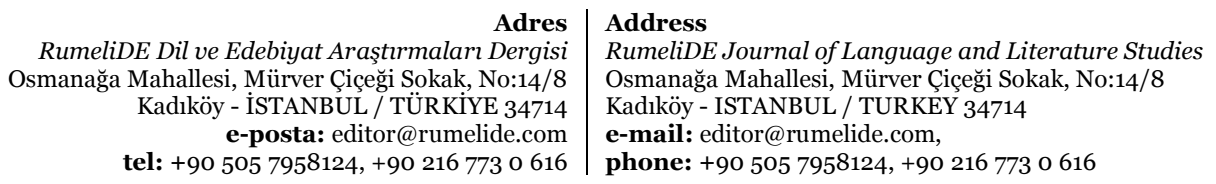


bilgi edinme yolları da farklılaşmıştır. Kâğıt ve kalem devri sonlandırılarak bilgi teknolojileri araçları, eğitim ve öğretim sürecinin en önemli parçalarından biri haline dönüşmüştür. Hayatın her sahasında olduğu gibi eğitim alanında da bireyleri, çağın yeni düşünce yapısının ortaya çıkardığı bu araçları kullanabilme yeterlilikleriyle donatmaya ve eğitim sürecinin bileşenlerini bu yeniliklerle özdeşleştirmeye çalışmaktadır.

Bu değişimin algılanması ve hayata geçirilmesi için tüm dünyada 21. yüzyıl becerilerinin tanımlanması ve bu zamanın dilini keşfetmiş kaliteli iş gücünün yetiştirilmesine ilişkin çeşitli kurumlar tarafından birçok çalışma yapılmıştır. Bu kurumlar arasında Uluslararası Eğitimde Teknoloji Topluluğu/ International Society for Technology in Education [ISTE], North Central Regional Educational Laboratory [NCREL], Avrupa Birliği/European Union [EU], Ekonomik İşbirliği ve Kalkınma Teşkilatı/ Organization for Economic Co-operation and Development [OECD], 21. Yüzyıl Öğrenme Ortaklı̆̆ı/ Partnership for 21st Century Learning [P21]) en önemlileri olarak sayllabilir. American Association of School Librarians (AASL)'ın 21. Yüzyıl Öğrenen Standartları olarak tanımladığı bu nitelikler; bilgi edinmeden yeni bilgi üretmeye ve bu üretimi kişisel ve estetik gelişimle taçlandırmaya eriştirecek 81 standarttan oluşmaktadır (AASSL, 2017). Bunlar içerisinde ise en yaygın etkiye sahip olan stratejik eğitim projesi olarak tanımlanan "Partnership for 21st Century Learning (P21)/ 21. Yüzyll Öğrenme Ortaklığı” adlı proje (P21 Leadership States, 2017), öğrenme-öğretme sürecinin merkezinde yer alacak 21. yüzyıl becerileri, öğrenme çıtıları ve destek sistemlerin tanımlandığı ortak bir paradigma belirlemiştir (P21, 2015; 2016; 2018'den aktaran Gelen, 2017).

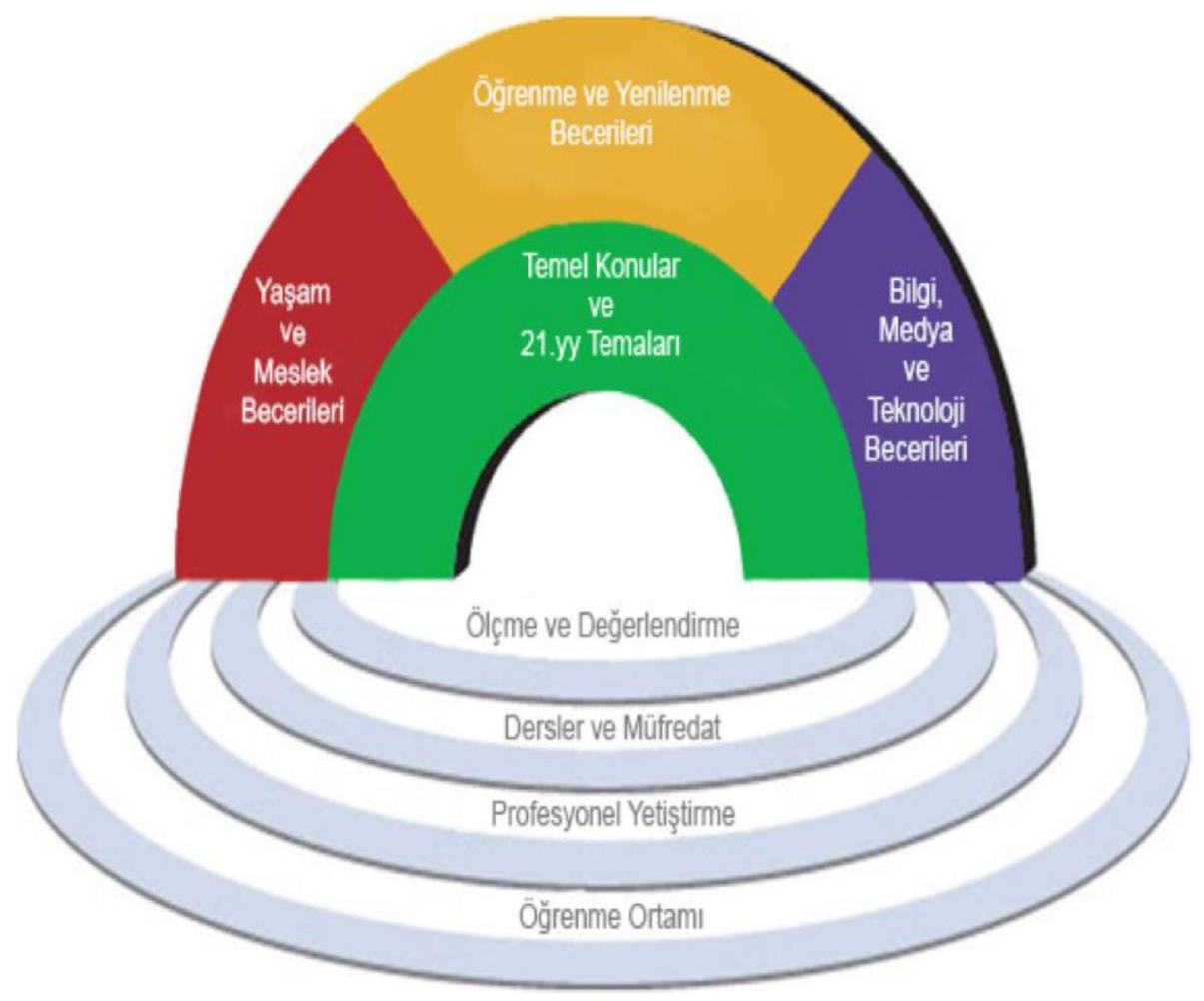

Şekil 1. 21. Yüzyıl Öğrenme Çerçevesi (Öğrenme Çıktıları ve Destek Sistemleri)

Bu çerçeve; içerik bilgisi, temel öğrenme becerileri uzmanlığı ve dil yeterliklerine ilişkin her bileşenin sarmal bir şekilde etkileşiminden oluşmaktadır. Buradaki renkli kısımlar "öğrenme çıktılarını”, gri kısımlar ise "destek sistemlerini" sembolize etmektedir (Gelen, 2017; Orhan Göksün, 2016). Bu çıktılar

\footnotetext{
RumeliDE Dil ve Edebiyat Araştırmalar Dergisi Osmanağa Mahallesi, Mürver Çiçeği Sokak, No:14/8 Kadıköy - İSTANBUL / TÜRKIYE 34714 e-posta: editor@rumelide.com tel: +90 $5057958124,+902167730616$

Address

RumeliDE Journal of Language and Literature Studies Osmanağa Mahallesi, Mürver Çiçeği Sokak, No:14/8

Kadıköy - ISTANBUL / TURKEY 34714

e-mail: editor@rumelide.com,

phone: +90 505 7958124, +90 2167730616
} 
içerisinde bireylerin sahip olması gereken 21. yüzyıl becerileri "öğrenme ve yenilenme becerileri”, "bilgi, medya ve teknoloji becerileri”, "yaşam ve meslek becerileri", "temel konular ve anahtar disiplinler öğrenme çıktılarını” oluşturmaktadır. Bu proje, her bileşenin alt becerilere ayrıldığı çoğulcu birliktelikten oluşan yapısını ortaya koyarken sürekli yenilenebilen dinamik bir yapıyı da teklif etmektedir. Destek sistemleri aşamasında ise 21. yüzyılda öğrenme ortamları, mesleki gelişim, uygulanan program ve öğretimi ile bu yüzyıla ait becerilerin ölçülüp değerlendirilmesini kapsamaktadır. Bu destek sistemleriyle 21. yüzyll becerilerinin kazanılmasında öğrenme ve öğretme sürecinin yaşamla birleştirilmesi amaçlanmıştır. 2015 yılında Dünya Ekonomik Forumu (World Economic Forum) ise 21. yüzyılda öğrencilerin sahip olması gereken becerilere ilişkin standartları yayınlamıştır (WEF, 2016).

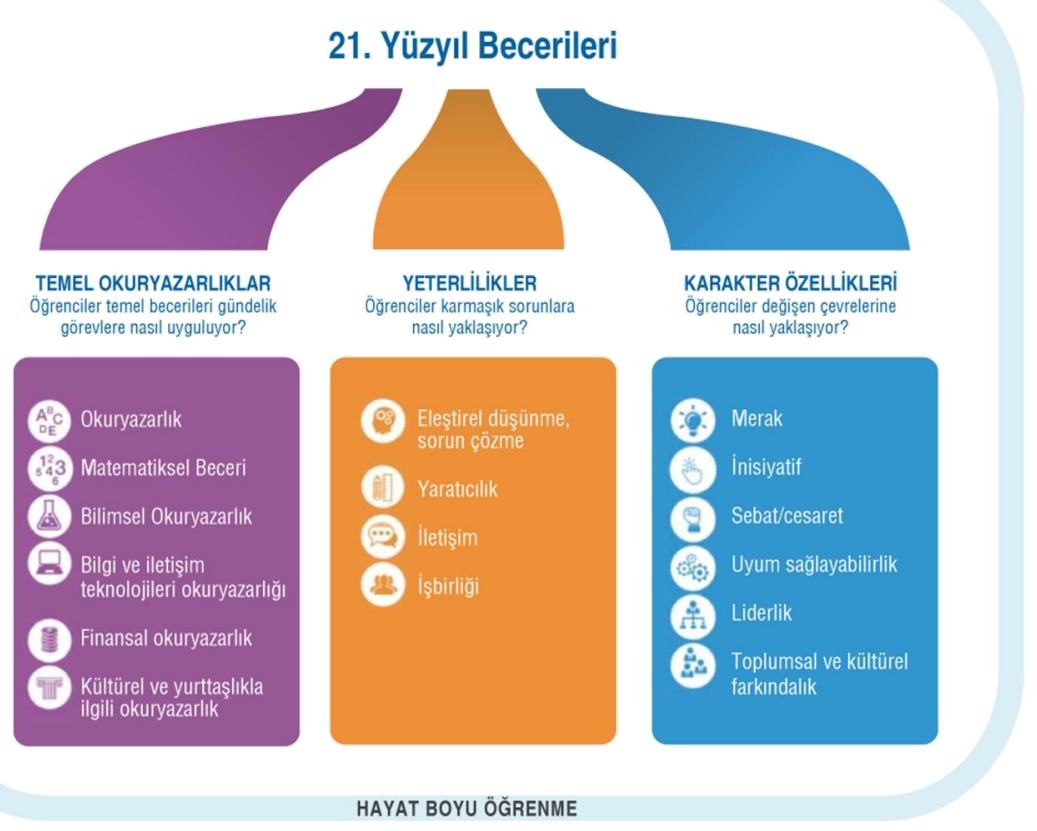

Şekil 2. 21. Yüzyll Becerileri (World Economic Forum, WEF, 2016)

Bu standartlar 21. yüzyıldaki paradigma değişikliğinin öğrenme ve öğretme sürecindeki yansıtmalarını göstermektedir. Toplumdaki dönüşümün mihenk taşı olan eğitim; dünyadaki ekonomik, kültürel ve sosyal alandaki bu hızlı değişimden çok ciddi oranda etkilenmektedir. Bu değişimi hazırlayan unsurlar ise küreselleşme, bilim ve teknoloji, nüfus ve göçler, ekonomi ve değerlerdeki değişim olarak kabul edilmektedir (Gültekin, 2020). Bu unsurların eğitim sistemindeki belirleyicileri ise teknolojik gelişim, interaktif, etkileşimli, uzaktan eğitim, uygulamalı eğitim ve ortamları, uluslararası eğitim ve ölçme değerlendirmeler, bilgiye ulaşım ve kaynakları, ekonomiklik, kültürellik, sosyallik, öğrenmeyi öğrenen, düşünen becerilere sahip, değerler eğitimini ve dil öğretimini kapsayan çoklu bir yapıdır (Gelen, 2017). Bu yapılanmanın eğitim sistemine adapte edilebilmesi için ülkeler teknolojik alt yapılarını inşa etmeli, alternatif öğrenme ve öğretme ortamlarına kendilerini hazırlamalıdırlar (Gelen, 2017).

Ülkemizde bu sürece uyumlanmak için öğretmen yeterlikleri, Temel Eğitime Destek Projesi (TEDP) adı altında Avrupa Birliği Komisyonu ile projelendirilerek 8 Şubat 2000 tarihinde imzalanan Finansman Anlaşmasıyla başlayıp ve 2002 yllında uygulamalara geçildiği bilinmektedir (Yavuz,

\footnotetext{
RumeliDE Dil ve Edebiyat Araștırmalar Dergisi Osmanağa Mahallesi, Mürver Ciceği Sokak, No:14/8 Kadıköy - ISTANBUL / TÜRKIYE 34714 e-posta: editor@rumelide.com

Address

RumeliDE Journal of Language and Literature Studies

Osmanağa Mahallesi, Mürver Çiçeği Sokak, No:14/8

Kadıköy - ISTANBUL / TURKEY 34714

e-mail: editor@rumelide.com

tel: +90 $5057958124,+902167730616$

phone: +90 505 7958124, +90 2167730616
} 
Özkaral ve Ylldız, 2015). Ardından 2008 yılında Avrupa Parlamentosunun belirlediği Avrupa Yeterlikler Çerçevesinden hareketle MEB, "Milli Eğitim Kalite Çerçevesi” ve "Türkiye Yeterlikler Çerçevesi” çalışmalarıyla bu beceriler, 8 anahtar yetkinlik olarak öğretim programlarında yer almıştır (TTKB, 2017). Bu gelişmelerin yanı sıra TÜSİAD (2012) tarafından yapılan 21. yüzyıl becerilerinin ve eğitimin niteliğinin tartışıldığı toplantılar, EARGED (2011)'in MEB 21. yüzyıl öğrenci profiline ilişkin yürüttüğü çalışmalar, eğitimin 21. yüzyll becerileriyle bütünleşmesi adına önemli adımlar arasında sayılabilir. Bu gelişmelerin ardından Türkiye Yeterlikler Çerçevesinde (TYÇ, 2015) eğitim sisteminde ve diğer öğrenme ortamlarında kazanılması gereken tüm yeterlilikler tanımlanmıştır. Bu çerçevenin ardından öğretim programlarında da değişikliklere gidilmiş "Milli Eğitim Kalite Çerçevesi”, "MEB (2015-2019) Stratejik Planı”, "Öğretmen Strateji Belgesi (2017-2023)”, “21. Yüzyıl Becerileri”, "Bilgi Toplumu Stratejisi ve Eylem Planı", “Değerler Eğitimi”, "Hayat Becerileri” adıyla karşlık bulan yeniliklerle eğitim sürecinin yeni yüzylddaki elbisesi hazırlanmaya başlanmıştır (Gelen, 2017). Bu çalışmalar neticesinde eğitimde köklü bir dönüşüm başlamış ve tüm müfredatlarda değişime gidilmiştir.

$\mathrm{Bu}$ sürecin başlangıcı olarak kabul edilen Temel Eğitime Destek Projesinin bileşenlerinden biri de öğretmen eğitimidir. Tüm dünya ülkelerinde öğretmen yetiştirme sürecinde kalitenin artırılmasına ilişkin çeşitli projeler yapılmış ve çeşitli raporlar yayınlanmıştır (Yavuz ve diğerleri, 2015). Yüksek öğrenim sektöründe bu değişimin açığa çıkışını yönlendiren trendler ve bu değişimin oluşturduğu yeni paradigmalar şu özelliklerle tanımlanabilir (Aktan, 2009).

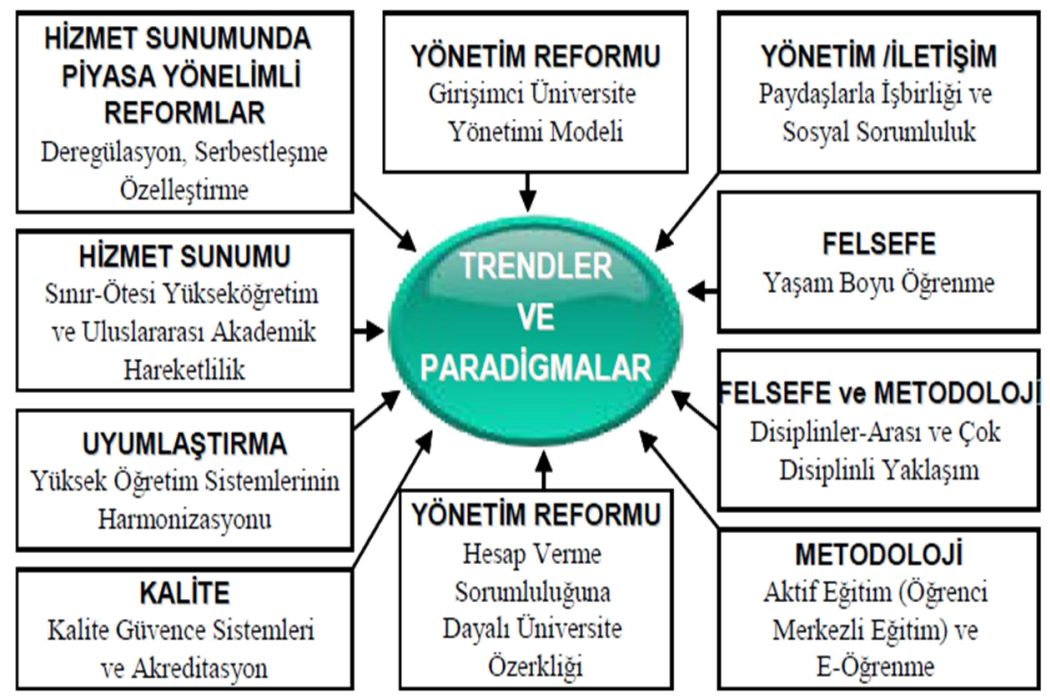

Şekil 3. Yükseköğretimde Global Trendler ve Yeni Paradigmalar (Aktan, 2009).

Ülkemizde ise MEB'in 2001 yılında “Çağdaş Öğretmen Nasıl Olmalı?” adıyla başlattığı ve günümüz öğretmen yeterliklerinin belirlenmesinin amaçlandığı çalışmalar sonucunda 2006 yılında "Öğretmenlik Mesleği Genel Yeterlikleri” yayınlanmıştır (MEB, 2009). Bu projeyle öğretmen yeterlilikleri; "kişisel ve mesleki değerler-mesleki gelişim; öğrenciyi tanıma; öğrenme ve öğretme süreci; öğrenmeyi, gelişimi izleme ve değerlendirme; okul, aile ve toplum ilişkileri; program ve içerik bilgisi” olarak tanımlanmıştır (MEB, 2006). Bu değişime adapte olabilmek için yapılan çalışmalardan bir diğeri de MEB’in öğretmen eğitiminde 2023 hedeflerini ortaya koyduğu Öğretmen Strateji Belgesidir (MEB, 2017). Bu çalışmalarla öğretmen eğitiminde kalitenin artırılmasında çok yönlü bir bakış açısı öğretmen eğitimi kalitesinin dünya standartlarına ulaştırılması amaçlanmıştır.

RumeliDE Dil ve Edebiyat Arașturmalar Dergisi Osmanağa Mahallesi, Mürver Çiçeği Sokak, No:14/8 Kadıköy - İSTANBUL / TÜRKIYE 34714 e-posta: editor@rumelide.com tel: +90 $5057958124,+902167730616$
Address

RumeliDE Journal of Language and Literature Studies

Osmanağa Mahallesi, Mürver Çiçeği Sokak, No:14/8

Kadıköy - ISTANBUL / TURKEY 34714

e-mail: editor@rumelide.com,

phone: +90 5057958124 , +90 2167730616 
21. yüzyıldaki gelişim ve değişimin etkisiyle yeniden tanımlanan öğretmenlik mesleği, bilgiyi aktaran öğretmen anlayışından çă̆ın yeterlikleriyle donanmış rehber rolündeki öğretmen anlayışına geçişi sağlamıştır. Öğretmen Strateji Belgesinde (MEB, 2017), öğretmenin sahip olması gereken yetkinlikleri; mevcut değişiklikleri özümseme, çağın yeterlilikleriyle donanma, üst düzey becerilere sahip olma ve kendini sürekli yenileyebilme olarak tanımlamaktadır. Bu değişikliklerle sadece pedagojik alan bilgisi açısından değil mesleki ve kişisel açıdan da yetkin öğretmenlerin yetiştirilmesi amaçlanmaktadır (Seferoğlu, 2004). 21. Yüzyılda öğretmenlik mesleğini pedagojik açıdan daha kapsamlı tanımlamak için Orhan Göksün (2016) tarafından da bir değerlendirme yapılmıştır. Bu değerlendirmede; MEB’in genel öğretmen yeterlikleri, teknolojik yeterliklerin tanımlanmasında öğretmenler için ISTE standartları, öğretmen bakış açısıyla sınıf içinde 21. yüzyll pedagojisinin işe koşulabileceği etkinlikleri incelemek için Lemov (2010)'un tanımladığı etkili iletişimin 49 tekniği ve öğretim programlarında öğretmenlik meslek becerisi ölçütlerini tanımlayabilmek için Melvin’in (2011) "Nasıl iyi öğretmen olunur?” çalışmasına ilişkin ölçütler sentezlenmiştir (Şekil 4):

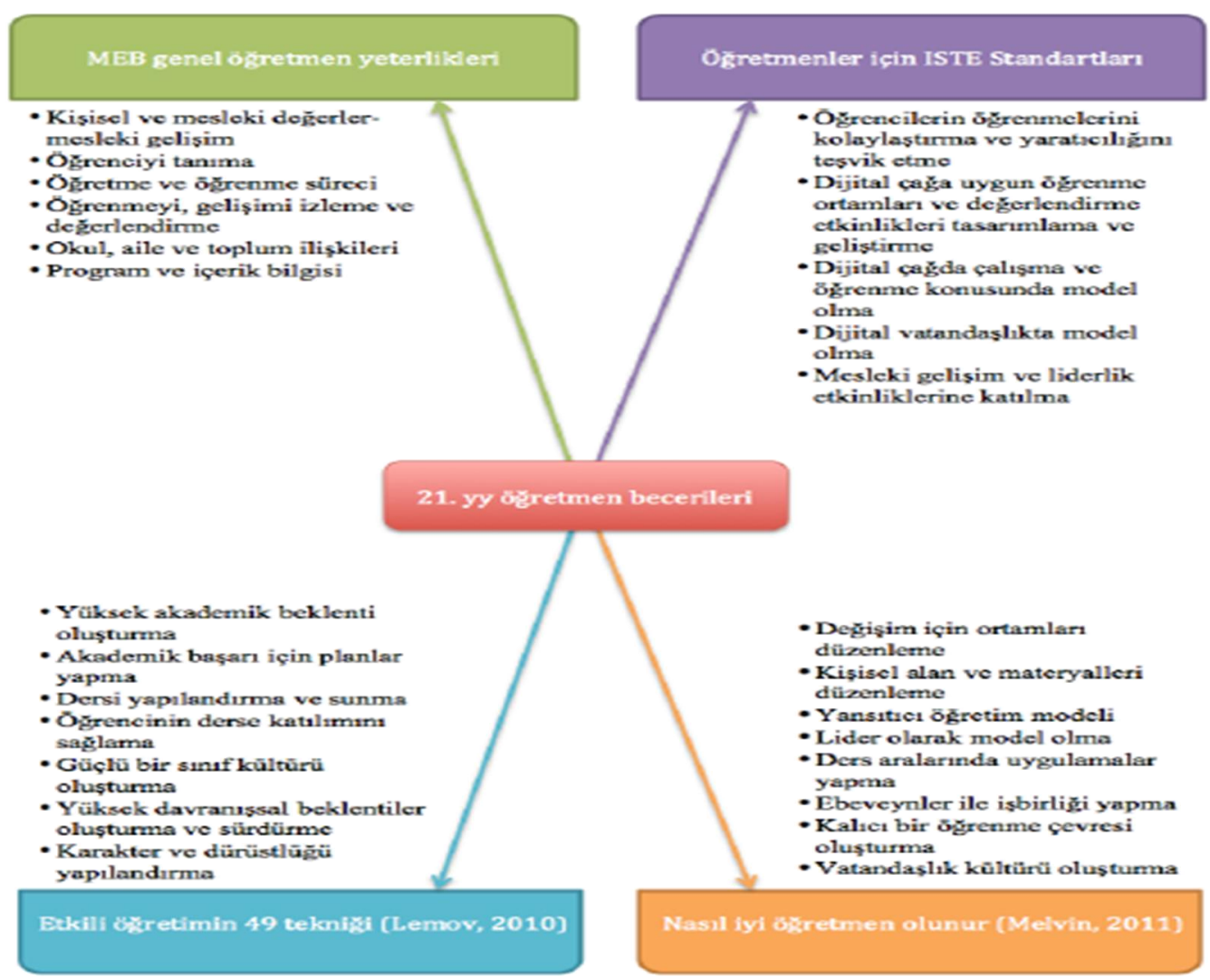

Şekil 4. 21. Yüzyılda öğretmen becerileri (Orhan Göksün, 2016).

Öğretmenlik mesleğine ilişkin yapılan bu çalışmaların temelinde, dünyaca kabul gören anlayış hakimdir. Bu anlayışa göre eğitimle ilgili dönüşümlerin uygulamaya geçirilmesinde öğretmenlerin anahtar role sahip olduğu, öğretmenlerin içselleştirmediği ve benimsemediği hiçbir reform girişiminin başarılı olmayıp sınıf ortamına yansımadı̆̆ına ilişkin bilgi yatmaktadır (MEB, 2017). Benzer şekilde Avrupa Toplulukları Komisyonunun (2008) raporuna göre öğrenci performansını etkileyen en önemli faktörün öğretmen kalitesi olduğu belirtilmiştir (Aktaran Yavuz ve diğerleri, 2015). Eğitim sisteminde 21. yüzyll becerilerine ilişkin değişimin hayata geçirilmesi, bu değişimin farkında varmış ve bu değişime göre kendini güncelleyebilen özgün öğretmenlerle sağlanacaktır (Altınpulluk ve Yıldırım,

\footnotetext{
RumeliDE Dil ve Edebiyat Araştırmalar Dergisi Osmanağa Mahallesi, Mürver Ciceği Sokak, No:14/8 Kadıköy - ISTANBUL / TÜRKIYE 34714 e-posta: editor@rumelide.com tel: +90 $5057958124,+902167730616$ 
2020; Çelikten, Şanal ve Yeni, 2005). Çünkü öğretmenler sınıfta, okulda ve toplumda "değişimin ajanları” olarak geleceği şekillendiren itici güçtür (Bourn, 2015’ten aktaran Gültekin, 2020).

Geleceğe hazır olan öğretmenlerin bu nitelikleri; küresel düşünme, çok kültürlülüğe duyarlı olma, değer oluşturmada rol model olma, yeni teknolojileri öğrenme ve kullanma, dijital ayak izi oluşturma, iş birliği yapma ve birlikte çalışma, esnek olma ve uyum sağlama, yenilikçi olma, tasarımcı bakış açısına ve sanatçı duyarlılığına sahip olma, öğrenme isteği duyma ve yaşam boyu öğrenen olma olarak tanımlanmaktadır (Gültekin, 2020). Bu tanımlama günümüzde online eğitimin kazanmış olduğu ivme ve dünyadaki hızlı değişimle birlikte okunduğunda farkındalık seviyesi yüksek ve kendini güncelleyebilen öğretmenlerin önemi daha da artmaktadır. Bir diğer taraftan günümüzde kullanabilir teknolojik araçlardan giyilebilir teknolojik araçlara doğru kayan yenileşmeyle teknolojik gelişimin çok daha üst düzeylere erişeceği öngörülmektedir. Bununla birlikte bu değişime adapte olabilme sürecinde olumsuz etkilerin de açığa çıkabileceği göz ardı edilmemeli, yeniliklerin yanı sıra bu değişimin ortaya çıkarabileceği olumsuzluklara karşı da öğretmenler bilinçlendirilmelidir. Mevcut yenilik ve gelişimlerle yeni eğitim ortamlarında oluşacak sorunların (güvenlik, teknolojik yönetim vb.) çözümü, yazılım ve robotların bazı alanlarda öğretmenin işlevini üstlenmesi, yüz yüze eğitimin azalması, eğitim ve öğretimin sürecinin ruhsuzlaşması gibi pek çok girift durumlarla da karşı karşıya kalınması beklenmektedir (Gelen, 2017). Bu olası ihtimaller ve mevcut teknolojik gelişmeler karşısında öğretmen eğitiminin önemini daha da artırmakta ve öğretmen eğitiminin perspektifinin geliştirilmesinin gerekliliğini ortaya koymaktadır. Bu durumda öğretmenlerin işinin daha zorlaştığını bunun yanı sıra eskiye nazaran çok daha çeşitli yetkinliklerle donanmalarının gerekli olduğunu göstermektedir. Erten (2019)'e göre de yükseköğretim kurumları akademik yetkinliklerin geliştirilmesinde küresel rekabete, teknolojik değişim ve gelişime uygun becerileri kazandırmanın yanı sıra bunları sürekli güncelleyebilecek devinimde olmalıdır. Bu değişim ve gelişime adapte olabilmek nitelikli bir hizmet öncesi öğretmen eğitiminin sağlanması, sürekli mesleki eğitimden geçmeyi gerekli kılmaktadır. Bunların yanı sıra uluslararası niteliklere sahip ancak ulusal nitelikleri koruyacak kaliteli alt yapıların oluşturulması da küreselleşen dünyada var olabilmek için vazgeçilmez bir zorunluluktur. Çünkü bu hızlı değişim, ulus devletleri tek tipleştirici eğilime yönlendirmekte ve milli kültürleri zayıflatıcı bir etki oluşturmaktadır. Oysaki devletlerin varlığını koruması için milli kimliğin ve kültürün çağın değerleriyle harmanlanıp üretilerek gelecek nesillere aktarılması ve devamlılı̆ının sağlanması gerekmektedir. Ülkemizin hedefi de inşa ettiği milli kimliğiyle evrensele doğru kucak açmış, entelektüel, estetik zevk sahibi, lider vasıflı bireylerin yetiştirilmesini sağlayan bir eğitim anlayışıdır (MEB, 2017). Benzer şekilde YÖK Lisans Programında (2018) bu duruma şöyle belirtilmektedir:

\begin{abstract}
Hızla değişen dünya ve ülkemiz insani, kültürel ve ahlaki krizler ve sorunlarla karşı karşıya kalmaktadır. Değerlerin giderek yitirilmesine ve kaybolmasına yol açan bu durum, ahlaklı ve erdemli bireye olan ihtiyacı giderek artırmaktadır. Etik, ahlaki ve kültürel değerlerin önem kazandığı günümüzde, öğretmenlerin alanıyla ilgili mesleki bilgi ve beceriler yönünden yeterli bir donanıma sahip olmalarının yanı sıra sosyal, kültürel, ahlakî ve entelektüel yönlerden donanımlı ve gelişmiş bir kişiliğe sahip olmaları ve daha insani ve erdemli bir dünyanın inşasında etkin rol almaları beklenmektedir. Bu nedenle öğretmenlerin evrensel, milli ve yerel/bölgesel kültürleri ve bunlar arasındaki ortak ve farklı yanları tanıyan, kültürel, etik, ahlaki değerler ve kişilik yönünden rol model olması gerekmektedir (YÖK, 2018).
\end{abstract}

Öğretmen eğitiminde YÖK’ün bakış açısı da alan bilgilerindeki nitelikli eğitimin yanı sıra kişilik gelişimlerinin de tamamlandığı üstün niteliklerle donanmış öğretmenler yetiştirmektir. World Economic Forum da 21. yüzyll yeterliliklerine ilişkin tanımlamada bu duruma vurgu yapılarak sosyal ve duygusal beceriler de ön plana çıkarılmış ve bu beceriler, karakter özellikleri kapsamında ayrı bir kategoriyle tanımlamıştır (WEF, 2016). Bu değişikliklerle öğretmenin, her yönden kuşatıcı ve üst düzey yeterliliklerle donanmış olarak mesleğe hazırlanması gerektiği vurgulanmıştır. Bu bakış açısıyla

\title{
Adres $\mid$ Address
}

RumeliDE Dil ve Edebiyat Araştırmaları Dergisi $\quad$ RumeliDE Journal of Language and Literature Studies Osmanağa Mahallesi, Mürver Çiçeği Sokak, No:14/8 Osmanağa Mahallesi, Mürver Çiçeği Sokak, No:14/8

Kadıköy - İSTANBUL / TÜRKIYE 34714 Kadıköy - ISTANBUL / TURKEY 34714 e-posta: editor@rumelide.com tel: +90 505 7958124, +90 2167730616 phone: +90 505 7958124, +90 2167730616 
yeni öğretmen modeli "sanatçı olarak eğitimci" ifadesiyle tanımlanmaktadır (Gültekin, 2020). Bu yüzyılın ideal öğretmeni, yaptığı işi bir sanat olarak görerek dönüştürmeye yardımcı olduğu zihinleri bir tuval olarak tasavvur edebilen, bu işin öğretmekten öte bir sanat olduğunu fark edebilmiş olmalıdır (Gouros, 2016'dan aktaran Gültekin, 2020). Öğrencinin biricik ve tek olduğunu idrak eden ideal öğretmen, eğitimin nihai hedefi olan "kendini gerçekleştirme (keşfetme)" sürecinde öğrenciyi bir sanatçı duyarlılığıyla yetiştirecek donanıma sahip olmalı ve bu duyarlılığı en yetkin şekilde kullanabilmelidir.

Öğretmenlik mesleğinin toplumdaki değişimin anahtar rolü çağın özellikleriyle birlikte okunduğunda bu mesleği devingen bir yapıda olduğu görülmektedir. Bu devingenlik öğretmen eğitimindeki çalışma ve arayışları da yönlendirici bir güçtür. Türk eğitim sisteminde daha kaliteli ve yetkin öğretmenler yetiştirmeye olan ihtiyaç da bu devingenliğe uyum sağlama çalışmalarının sonuçlarıdır. Söz sahibi olmanın motivasyon açısından etkisi düşünüldüğünde 2023 hedeflerine ulaşmada 21. yüzyılda öğretmen profiline ilişkin tanımların çeşitli paydaşlar tarafından ortaya konulmasının kaliteli öğretmenlerin yetiştirilmesine ilişkin düzenlemelere ve yapılacak revizyonlara olumlu katkı sağlayacağı düşünülmektedir. Bu araştırmayla da bu sürece katkı sağlayarak ana dili öğreticileri olan Türkçe öğretmenlerinin 21. yüzyılda sahip olması gereken yeterliliklerinin öğretmen adaylarının bakış açlarıyla betimlenmesi amaçlanmış ve araştırmada şu soruya cevap aranmıştır:

1. Türkçe öğretmeni adaylarına göre Türkçe öğretmenleri 21. yüzyılda hangi yeterliliklere ve değerlere sahip olmalıdır?

\section{Araştırmanın modeli}

Nitel araştırma yöntemiyle gerçekleştirilen bu araştırmada durum çalışması deseni kullanılmıştır. Bu desende bir durum hakkında çoklu bilgi kaynaklarıyla detaylı ve derinlemesine bilgi toplanılması ve durumun en ince ayrıntılarıyla tanımlaması amaçlanmaktadır. Bu desende, değişkenler arasındaki sebep-sonuç ilişkileri, genelleme yapılmadan mevcut durumdan bir kesit alarak durum ayrıntılı bir şekilde yansitılır (Creswell, 2012). Bu araştırmayla Türkçe öğretmenlerinin 21. yüzyllda sahip olması gereken yeterliliklere ilişkin öğretmen adaylarının bakış açılarının derinlemesine ortaya konulması amaçlanmıştır. Öğretmen yeterlilikleri sürekli gelişip yenilendiği için Türkçe öğretmeni profiline ilişkin bu betimlemenin, öğretmen eğitimindeki beklentilerin ortaya konulması açısından alan yazına önemli katkılar sağlayacağı düşünülmektedir.

\section{Çalışma grubu}

Çalışma grubunun belirlenmesinde amaçlı örnekleme yöntemlerinden kolay ulaşlabilir durum örneklemesi kullanılmıştır. Bu örnekleme yoluyla belirlenmiş olan katılımcılar, 2018 akademik yılında bahar döneminde Recep Tayyip Erdoğan Üniversitesi Türkçe Öğretmenliği Bölümünde 3. sınıfta öğrenim gören 34 öğretmen adayından oluşmaktadır.

\section{Veri toplama aracı}

$\mathrm{Bu}$ araştırmada, Türkçe öğretmeni adaylarının 21. yüzyılda Türkçe öğretmenlerinin sahip olması gereken yeterliliklere ilişkin görüşlerini tespit etmek amacıyla yarı yapılandırılmış görüşme formu kullanılmıştır. Katılımcılarla belli bir forma dayalı olarak yapılan bu görüşme türüyle daha sistematik ve karşılaştırılabilir bilgi elde edilirken araştırma problemiyle ilgili istenen boyutların güvence altına alınması sağlanır (Patton, 2002). Bu formla katılımcıların fikirlerini daha derinlemesine açıklaması,

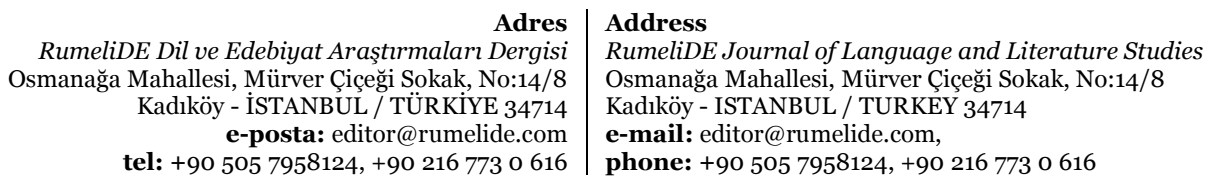


yanlış anlamaların azaltılması, bireyselliğin korunması ve durumun katılımcının bakış açısıyla değerlendirmesi amaçlanmıştır (Cohen, Manion \& Morrison, 2011).

Araştırmada kullanılan bu formun hazırlanmasında ilgili alan yazın taramasının ardından üç açık uçlu soru oluşturulmuştur. Bu form; konu kapsamı, soruların soruş biçimi, soruların anlaşlabilirliği gibi noktaların incelenmesi açısından iki alan uzmanına sunulmuştur. İlgili forma alan uzmanları tarafından verilen dönütler neticesinde soru sayısı ikiye düşürülmüş ve veri toplama aracına son şekli verilmiştir. Bu form aracılı̆̆ıyla katılımcılara şu sorular yöneltilmiştir:

1. Türkçe öğretmenlerinin 21. yüzyılda sahip olması gereken yeterlilikleri tanımlar mısınız?

2. Türkçe öğretmenlerinin 21. yüzyılda sahip olması gereken değerleri tanımlar mısınız?

\section{Verilerin analizi}

Nitel araştırmalarda analiz, elde edilen veri yığınını gözlemlemek ve tümevarımsal bir yaklaşımla bunları organize ederek anlaşılabilir bir düzene ulaşma süreçlerinden oluşur (Creswell, 2013). Verinin indirgenmesi ve yorumlanması olarak değerlendirilen veri analiz yöntemlerine ilişkin çeşitli paradigmalar ileri sürülmekle birlikte bu araştırmada Creswell (2013) tarafından belirlenen nitel veri analiz basamakları temel alınmıştır: i) veriyi organize etme, ii) veriyi ön okuma, iii) kodlama ve temalara ulaşma ve iv) veriyi sunma ve yorumlama. Bu doğrultuda ilk olarak görüşme kayıtları yazılı hale getirilmiştir. Görüşme sonucunda elde edilen verilerin kodlanmasında sözcük, tümce ve paragraflardan yola çıkarak alan yazına dayalı olarak kodlar oluşturulmuştur. Benzerlikleri ortaya konan kavramlardan kodlar, kodlardan da temalar oluşturularak elde edilen bulgular tablolar ve grafikler şeklinde sunulmuştur.

Araştırmada elde edilen verilere ilişkin kodlama işleminin ardından belirlenen kod ve temalar birbirinden bağımsız iki uzmanın görüşüne sunulmuştur. Uzmanların ve araştırmacının, kod ve tema listelerine ilişkin yaptıkları değerlendirmelerde görüş birliği ve görüş ayrıllğı olan kodlamalar tespit edilmiş, görüş ayrıllğına düşülen durumlarda yeniden kodlama yapılmıştır. Araştırmacılar ve uzmanlar arasındaki görüş birliği ve ayrılıklarının, araştırmanın güvenirliği üzerindeki etkisi Miles ve Huberman’ın (1994) formülünden [Görüş birliği/ (Görüş birliği+Görüş ayrıllğı) x 100] yararlanılarak yapılmış ve bu inceleme sonucunda araştırmacılar ve iki uzmanın görüşleri arasındaki uzlaşma (güvenirlik) \%89 ve \%90 olarak belirlenmiştir. Bu oran kodlayıcılar arasında yüksek bir tutarlılık sağlandığını ve bu tutarlığın güvenilir olduğunu ortaya koymaktadır.

Araştırmada iç geçerliği artırmak amacıyla veri toplama aracının hazırlanmasında uzman görüşüne başvurulmuştur. Araştırmanın güvenirliğini artırmak amacıyla da verilerin analiz sürecinde bir başka araştırmacının da görüşlerine başvurularak, tutarlılıklar ve çelişkilere dayalı olarak ortaya çıkan farklılıklar değerlendirilerek temalar ortaya konulmuştur. Araştırmanın dış geçerliliğini artırmak amacıyla doğrudan alıntılara yer verilmiştir.

\section{Bulgular}

Araştırmanın bu bölümünde, öğretmen adaylarının Türkçe öğretmenlerinin 21. yüzyılda sahip olması gereken yeterliliklere ilişkin görüşlerinden elde edilen bulgulara yer verilmiştir. Bu bulgular özel alan yeterlilikleri, kişisel yeterlilikler ve değerler olmak üzere üç tema altında toplanmıştır.

\begin{tabular}{|c|c|}
\hline & \\
\hline aları $D$ & d Literatur \\
\hline $\mathrm{Mal}$ & Mahallesi, Mürver Çiçeği Sokak, No:14/8 \\
\hline Kadıköy & STANBUL / TURKEY 34714 \\
\hline $\begin{array}{r}\text { e-posta: edito } \\
\text { tel: }+905057958124,+\end{array}$ & $\begin{array}{l}\text { editor@rumelide.com, } \\
\text { +90 505 7958124, +90 } 216773 \text { o } 616\end{array}$ \\
\hline
\end{tabular}


Tablo 1. Türkçe öğretmenlerinin sahip olması gereken özel alan yeterliliklerine ilişkin görüşleri

\begin{tabular}{|c|c|c|c|}
\hline \multirow{2}{*}{ Özel Alan Yeterlilikleri } & \multirow{2}{*}{$\begin{array}{l}\operatorname{Kadın}_{(24)} \\
f\end{array}$} & \multirow{2}{*}{$\begin{array}{l}\text { Erkek(10) } \\
f\end{array}$} & \multirow{2}{*}{$\begin{array}{l}\text { Toplam }_{(34)} \\
\mathbf{f}\end{array}$} \\
\hline & & & \\
\hline Teknolojinin derste etkin kullanımı & 19 & 9 & 28 \\
\hline Türkçenin ve temel dil becerilerinin etkin kullanımı & 17 & 6 & 23 \\
\hline Sınıfta etkili iletişim ortamı oluşturma & 17 & 5 & 22 \\
\hline Ö ğretim sürecini planlama ve zamanı aktif kullanım & 13 & 4 & 17 \\
\hline Meslektaşlarıyla iş birliği & 11 & 1 & 12 \\
\hline Disiplinler arası bakış açısı & 10 & 1 & 11 \\
\hline Alandaki yenilikleri takip etme & 8 & 2 & 10 \\
\hline Öğrencilere rol model olabilme & 8 & 2 & 10 \\
\hline Farklı ve yeni yöntem, strateji ve tekniklerin kullanımı & 5 & 3 & 8 \\
\hline Çalışma disipline sahip olma & 5 & 1 & 6 \\
\hline Yaratıcı materyaller hazırlayabilme & 5 & - & 5 \\
\hline Stratejik soru sorabilme & 4 & 1 & 5 \\
\hline Bireysel farklılıkları dikkate alma & 4 & - & 4 \\
\hline İşini sevme & 3 & - & 3 \\
\hline
\end{tabular}

Grafik 1. Türkçe öğretmenlerinin sahip olması gereken özel alan yeterliliklerine ilişkin görüşleri

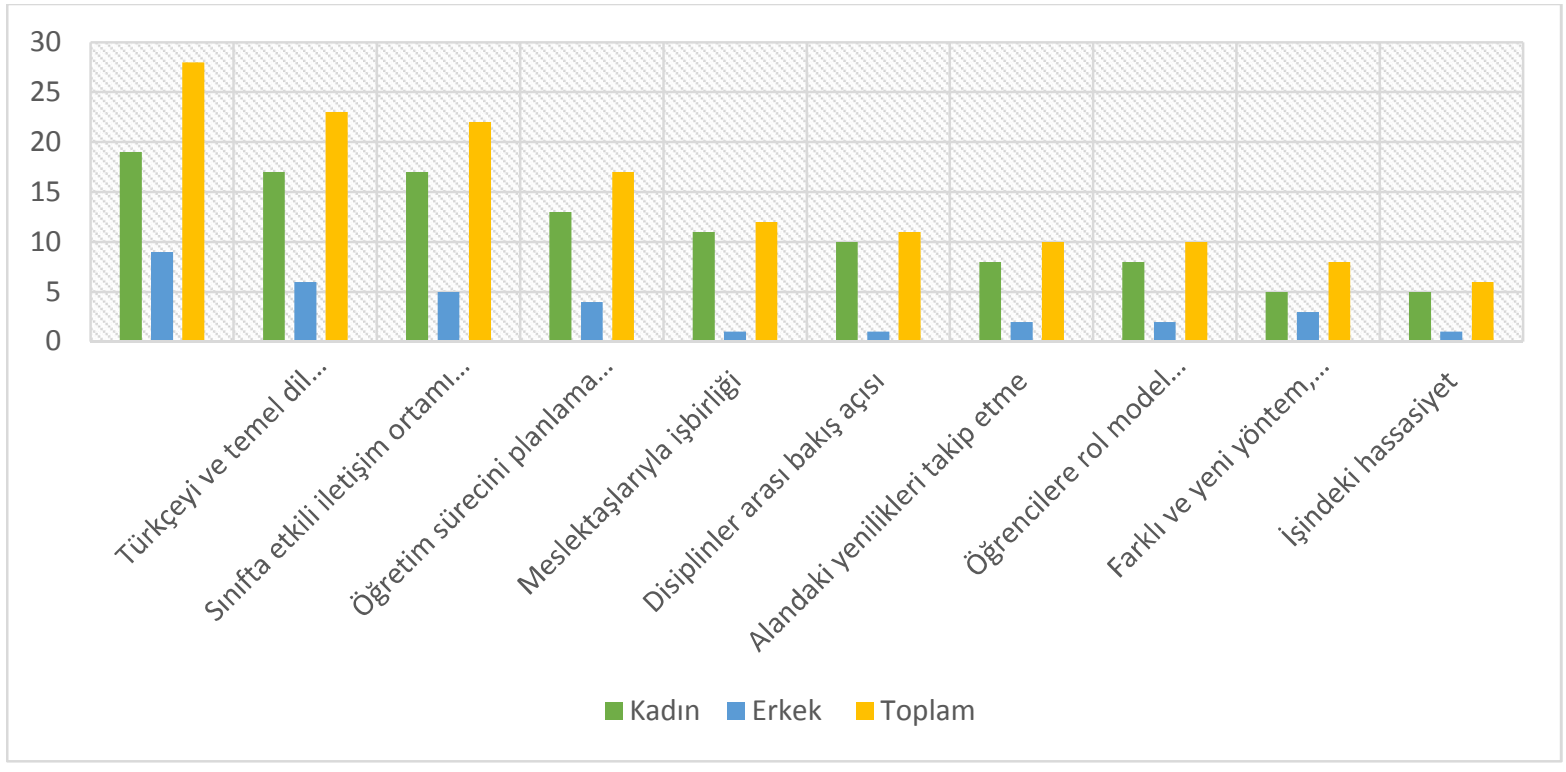

Tablo ve Grafik 1'de kadın, erkek ve tüm öğretmen adaylarına ilişkin yapılan değerlendirmede özel alan yeterlilikleri içerisinde en yüksek frekansa sahip olanlar; teknolojinin derste etkin kullanımı $(f=19)$, Türkçenin ve temel dil becerilerinin etkin kullanımı $(f=17)$, sınıf içerisinde etkili iletişim becerisine sahip olma $(f=17)$, öğretim sürecini planlama ve zamanı aktif kullanım $(f=13)$ olarak sıralandırılabilir. Ayrıca kadın öğretmen adayları ve tüm öğretmen adaylarına ilişkin değerlendirmede öğretim sürecini planlama ve zamanı aktif kullanım, meslektaşlarıyla iş birliği ve disiplinler arası bakış açısına sahip olmaya ilişkin yeterliliklerin en yüksek frekansa sahip olduğu tespit edilmiştir. Erkek

\begin{tabular}{r|l} 
Adres & Address \\
RumeliDE Dil ve Edebiyat Araşttrmaları Dergisi & RumeliDE Journal of Language and Literature Studies \\
Osmanağa Mahallesi, Mürver Çiçeği Sokak, No:14/8 & Osmanağa Mahallesi, Mürver Çiçeği Sokak, No:14/8 \\
Kadıköy - İSTANBUL / TÜRKIYY 34714 & Kadıköy - ISTANBUL / TURKEY 34714 \\
e-posta: editor@rumelide.com & e-mail: editor@rumelide.com, \\
phone: +90 505 7958124, +90 2167730616
\end{tabular}


öğretmen adayları tarafından ise yaratıcı materyaller hazırlayabilme, bireysel farklılıkları dikkate alma ve işini sevmeye ilişkin kodların hiç ifade edilmediği tespit edilmiştir.

Türkçe öğretmenlerinin 21. yüzyılda sahip olması gereken özel alan yeterliliklerine ilişkin görüşlerden bazıları şu şekildedir:

Türkçe öğretmenleri teknolojiyi kullanabilmeli ama asıl önemli olan bu araçlarla derste kullanabilecek farklı etkinlikler hazırlayabilmelidir $(\mathrm{K}, 8)$.

Teknolojiyi bilmeli ve bu araçları derse öğrenciyi aktif bir şekilde katabilmek için kullanacak profesyonellikte olmalıdır (K, 7).

Bilgi artık her yerde. Bu nedenle araştırma yapmaktan ziyade doğru bilgiye erişimdeki nitelikleri bilmelidir $(\mathrm{K}, 8)$.

Türkçeyi doğru ve güzel bir şekilde kullanmalı ancak dilindeki incelik davranışlarıyla örtüşmeli sosyal davranışlarında bunu gerçekleştirmelidir (K, 9).

Türkçe öğretmeni derse gelmeden önce mutlaka plan yapmalı. Bu planın yanı sıra öğretim sürecinde kullanabileceği uygun materyaller tasarlayabilmelidir. Öğrencilere iyi bir rol model olmalıdır (K, 15).

Tablo 2. Türkçe öğretmenlerinin sahip olması gereken kişisel yeterliliklere ilişkin görüşler

\begin{tabular}{llll}
\hline \multirow{2}{*}{ Kişisel Yeterlilikler } & Kadin(24) & Erkek(10) & Toplam(34) $^{(3)}$ \\
\cline { 2 - 4 } Yenilikçilik & $\boldsymbol{f}$ & $\boldsymbol{f}$ & $\boldsymbol{f}$ \\
Yaratıcllı & 17 & 5 & 22 \\
Eleştirel düşünebilme & 14 & 6 & 20 \\
Öğrenmekten zevk alma & 13 & 7 & 20 \\
Kendini tanıma & 17 & - & 17 \\
Yaşam boyu öğrenmeyi benimseme & 13 & 3 & 16 \\
Kendine güvenme & 14 & 2 & 16 \\
Araştırmacılık & 11 & 3 & 14 \\
Problem çözebilme & 11 & 3 & 14 \\
Merak & 10 & 2 & 12 \\
Analitik düşünme & 4 & 6 & 10 \\
Kendini güncelleyebilme & 5 & 2 & 7 \\
Sosyal ve girişken & 7 & - & 7 \\
Özgürlükçü ve özgün & 5 & 2 & 7 \\
Motivasyon & 6 & - & 6 \\
Esnek ve uyumlu olma & 3 & 1 & 4 \\
Önyargisız olma & 4 & - & 4 \\
Stresle başa çıkabilme & 3 & - & 3 \\
\hline
\end{tabular}

RumeliDE Dil ve Edebiyat Araştırmaları Dergisi Osmanağa Mahallesi, Mürver Ciçeği Sokak, No:14/8 Kadıköy - İSTANBUL / TÜRKIYE 34714 e-posta: editor@rumelide.com tel: +90 505 7958124, +90 2167730616
Address

RumeliDE Journal of Language and Literature Studies

Osmanağa Mahallesi, Mürver Çiçeği Sokak, No:14/8

Kadıköy - ISTANBUL / TURKEY 34714

e-mail: editor@rumelide.com,

phone: +90 505 7958124, +90 2167730616 
Grafik 2. Türkçe öğretmenlerinin sahip olması gereken kişisel yeterliliklere ilişkin görüşler

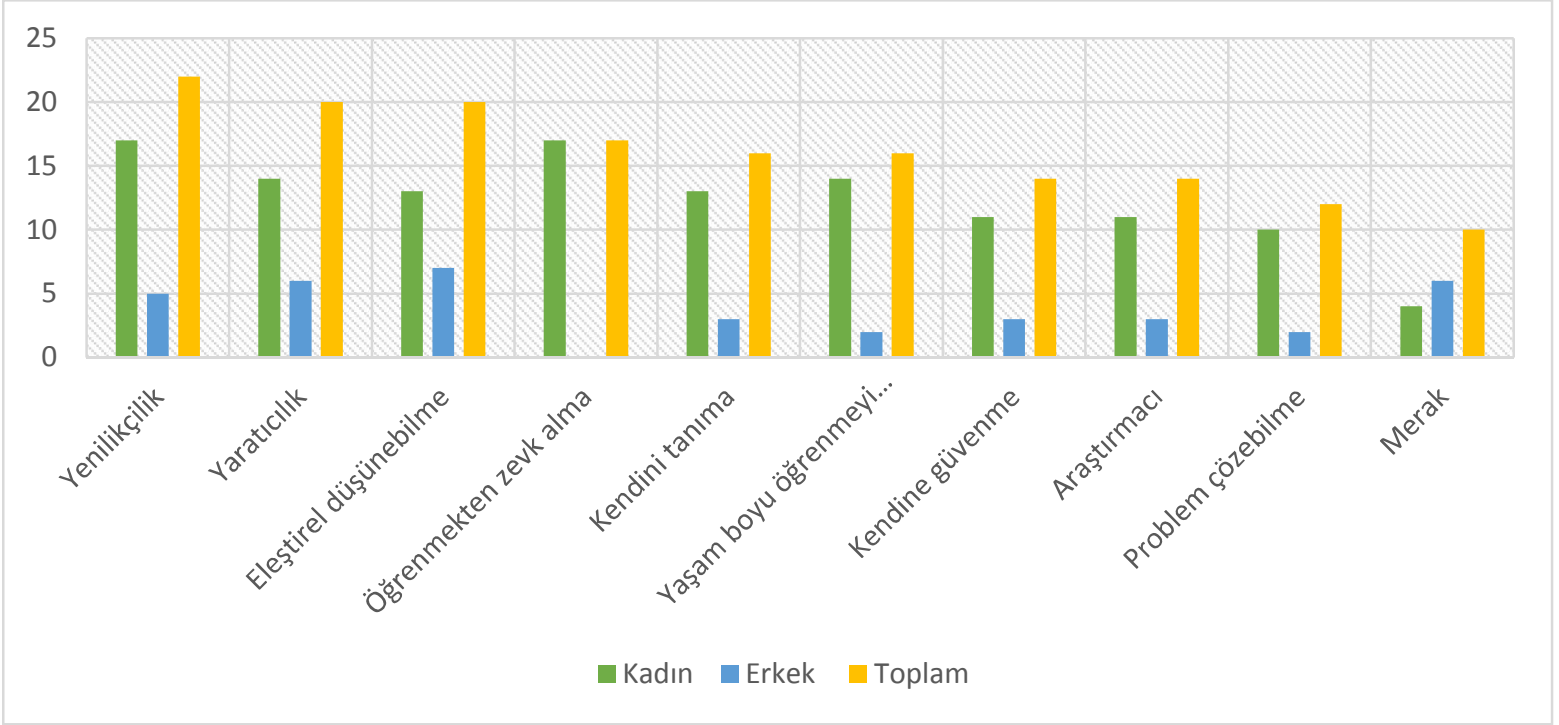

Tablo ve Grafik 2’ye göre kadın öğretmen adaylarının kişisel yeterliliklere ilişkin görüşleri içerisinde en yüksek frekansa sahip olanlar yenilikçilik $(f=17)$, öğrenmekten zevk alma $(f=17)$, yaratıcllık $(f=14)$, yaşam boyu öğrenmeyi benimseme $(f=14)$, kendini tanıma $(f=13)$ ve eleştirel düşünebilme $(f=13)$ yer almaktadır. Erkek öğretmen adayları açısından yapılan değerlendirmede ise eleştirel düşünebilme $(f=7)$, merak ( $f=6$ ), yaratıcılık ( $f=6$ ) ve yenilikçilik ( $f=5$ ) en yüksek frekansa sahip olan yeterlilikler olarak belirlenmiştir. Tüm öğretmen adaylarına ilişkin görüşler incelendiğinde ise yenilikçilik ( $\mathrm{f}=\mathbf{2 2})$, yaratıcllı ( $\mathrm{f}=20)$, eleştirel düşünebilme $(\mathrm{f}=20)$, öğrenmekten zevk alma $(\mathrm{f}=17)$ ve kendini tanıma $(\mathrm{f}=16)$ en yüksek frekansa sahip yeterlilikler olarak tespit edilmiştir. Erkek öğretmen adayları ise kendini güncelleyebilme, esnek ve uyumlu olma, önyargısız olma ve stresle başa çıkabilme kodlarına ilişkin hiç görüş bildirmemişlerdir.

Türkçe öğretmenlerinin 21. yüzyılda sahip olması gereken kişisel alan yeterliliklerine ilişkin görüşlerden bazıları şu şekildedir:

Yeniliklere açı bir öğretmen olmalı. Öğrencilerle birlikte öğrenebilecek idrakte olmalı ve kendini güncelleyebilmelidir (E, 1).

Türkçe öğretmeni öncelikle kendini tanımalıdır. Bunu başardığında kendi istek ve beklentilerini belirleyebilen biri olacağ için kendi gelişimi oranında öğrencileri geliştirecektir $(K, 22)$.

Türkçe öğretmeni öğrenmeyi seven, meraklı, yaşam boyu öğrenmeyi benimsemiş ve öğrenmeye ihtiyaç duyan biri olmalıdır (K, 22).

Türkçe öğretmeni kendini sürekli güncelleyebilmelidir $(K, 6)$.

Türkçe öğretmeni her zaman yeniliklere açık olmalıdır (E, 2).

Sorun olduğunda olayı tatlıya bağlamayı bilen bir üslubu olmalıdır (E, 5).

Üretken, yaratıcı ve hayal gücü gelişmiş bir kişi olmalıdır (E, 8).

Türkçe öğretmeni çağa ayak uydurabilmelidir (E, 7).

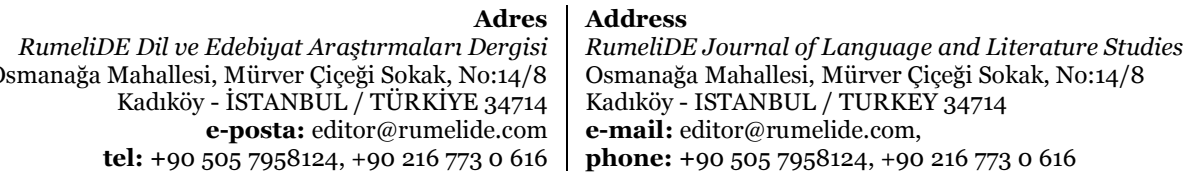


Tablo 3. Türkçe öğretmenlerinin sahip olması gereken değerlere ilişkin görüşler

\begin{tabular}{llll}
\hline \multirow{2}{*}{ Değerler } & $\operatorname{Kadın}_{(24)}$ & $\operatorname{Erkek}_{(10)}$ & Toplam $_{(34)}$ \\
\cline { 2 - 4 } & $f$ & $f$ & $f$ \\
\hline Saygı & 9 & 8 & 17 \\
Sevgi & 12 & 3 & 15 \\
Vatanseverlik ve milli değerlere bağlık & 11 & 3 & 14 \\
Hoşgörü & 8 & 2 & 10 \\
Adalet & 6 & 2 & 7 \\
Merhamet & 5 & 2 & 7 \\
Dürüstlük & 6 & 1 & 4 \\
Samimiyet & 4 & - & 3 \\
Yardımseverlik & 3 & - & 3 \\
Sabırlı olma & 2 & 1 & 3 \\
\hline
\end{tabular}

Tablo 3. Türkçe öğretmenlerinin sahip olması gereken değerlere ilişkin görüşler

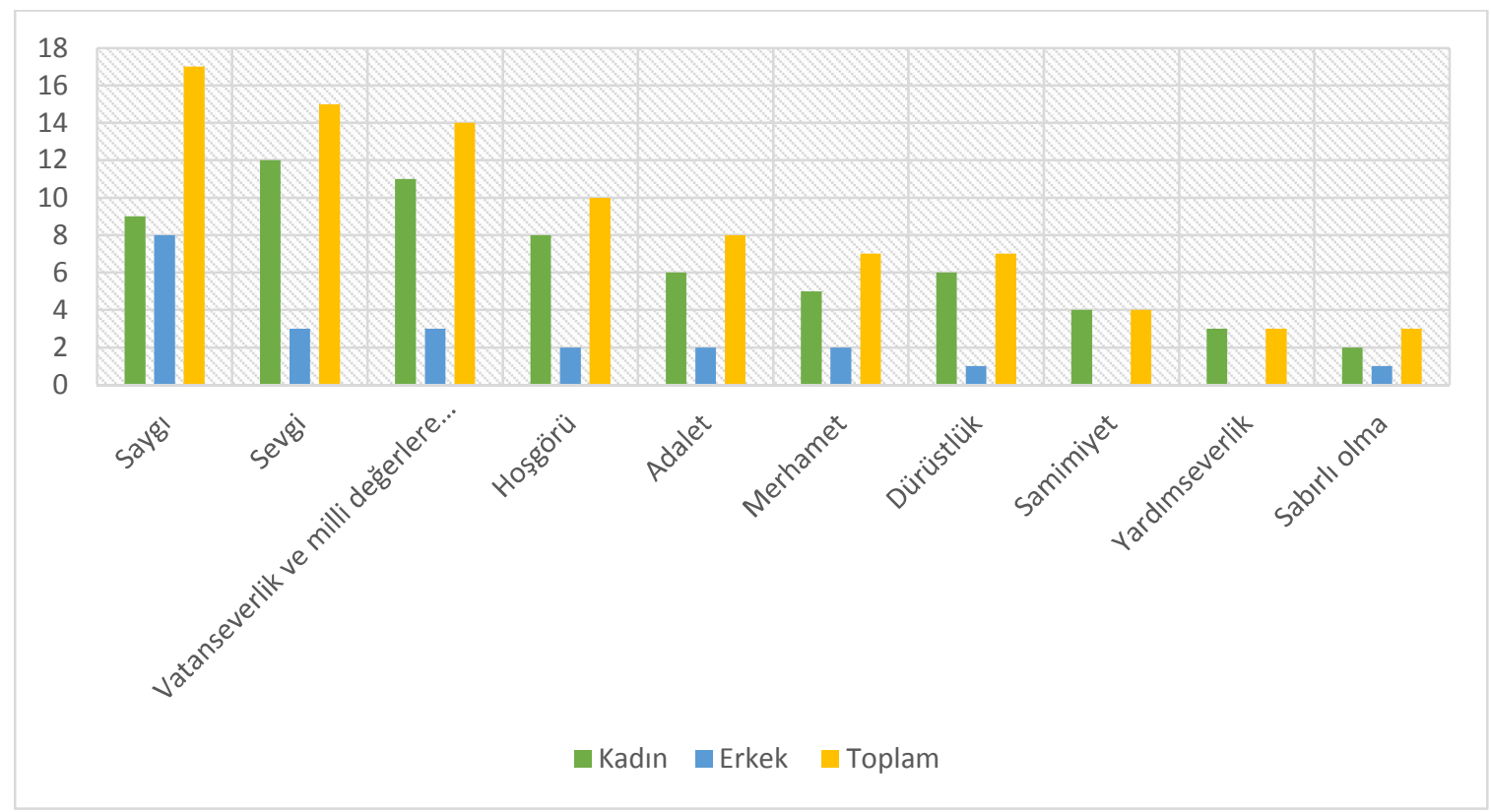

Tablo ve Grafik 3'e göre kadın öğretmen adayları tarafından en çok sevgi ( $\mathrm{f}=12$ ), vatanseverlik ve milli değerlere bağlılık ( $f=11)$, saygı $(f=9)$ ve hoşgörü $(f=8)$; erkek öğretmen adayları tarafından ise saygı $(\mathrm{f}=8)$, sevgi $(\mathrm{f}=3$ ) ile vatanseverlik ve milli değerlere bağlılık $\mathrm{f}=3$ ) en yüksek frekansa sahip değerler olarak belirlenmiştir. Tüm öğretmen adaylarına ilişkin yapılan değerlendirmede ise saygı ( $\mathrm{f}=17$ ), sevgi $(\mathrm{f}=15)$, vatanseverlik ve milli değerlere bağlılık ( $\mathrm{f}=14$ ) ile hoşgörü ( $\mathrm{f}=10$ ) olduğu tespit edilmiştir. Samimiyet ve yardımseverlik değerlerinin ise sadece kadın öğretmen adayları tarafından ifade edildiği görülmektedir.

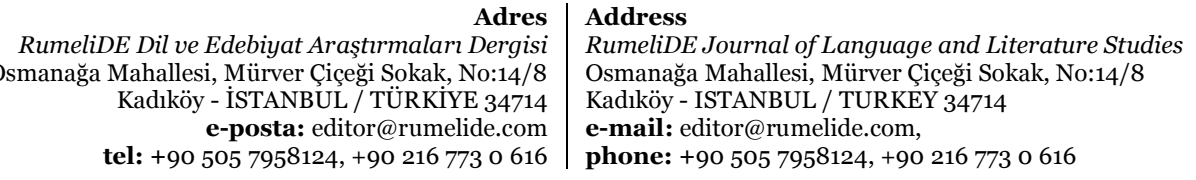


Türkçe öğretmenlerinin 21. yüzyılda sahip olması gereken değerlere ilişkin görüşlerden bazıları şu şekildedir:

Türkçe öğretmenleri sabırlı ve anlayışlı olmalıdır. Merhametli ve şefkatli olmalıdır (K, 6).

Saygilı, merhametli ve sorumluluk sahibi olmalıdır (E, 8).

Tarihini iyi bilmeli ve vatanını, milletini sevmelidir (E, 7).

Ahlaklı olmalı, gelenek ve göreneklerine bağlı olmalıdır. Bunun yanı sıra giyim kuşamına dikkat etmelidir. Demokratik haklara ve insan haklarına saygılı olmalıdır (E, 9).

İnsan olmak için sahip olunması gereken tüm değerlere sahip olmalıdır (E, 4).

İnsanları sevmeli, uyumlu olmalı, başkalarının mutluluğunu istemeli ve iyi bir insan olmalıdır (K, 18).

Türkçe öğretmeni merhamet sahibi olmalı, vicdan sahibi olmalı ve sevecen olmalıdır $(K, 17)$.

$\mathrm{Bu}$ araştırma sonucunda Türkçe öğretmenlerinin 21. yüzyllda sahip olmaları gereken en önemli yeterlilik ve değerler Şekil 5’te sunulmuştur.

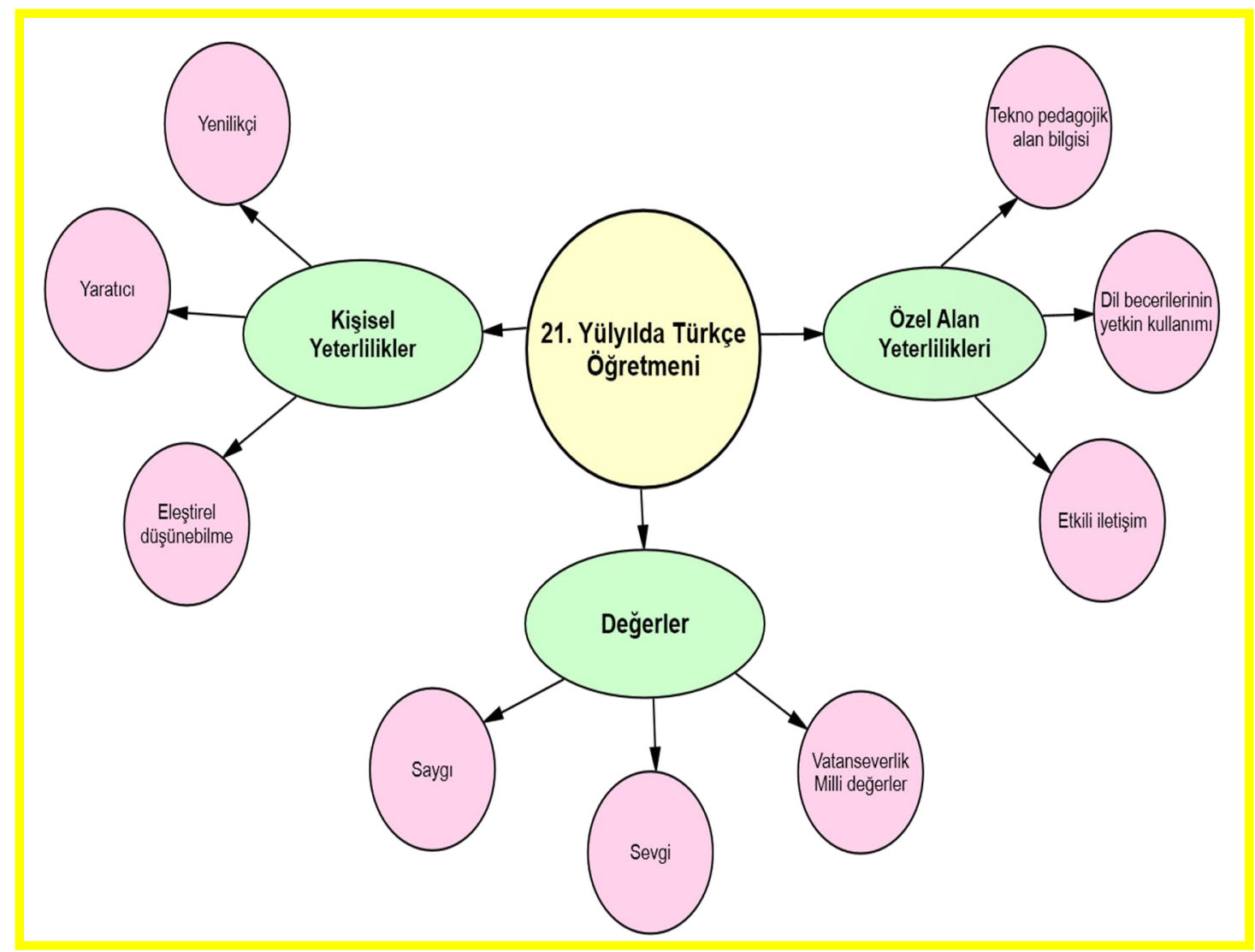

Şekil 5. 21. yüzyılda Türkçe öğretmeni modeli

RumeliDE Dil ve Edebiyat Araştırmalam Dergisi Osmanağa Mahallesi, Mürver Çiçeği Sokak, No:14/8

Kadıköy - İSTANBUL / TÜRKIYE 34714 e-posta: editor@rumelide.com

tel: +90 $5057958124,+902167730616$
Address

RumeliDE Journal of Language and Literature Studies

Osmanağa Mahallesi, Mürver Ciçeği Sokak, No:14/8

Kadıköy - ISTANBUL / TURKEY 34714

e-mail: editor@rumelide.com,

phone: +90 505 7958124, +90 2167730616 


\section{Tartışma ve sonuç}

$\mathrm{Bu}$ araştırmada Türkçe öğretmenlerinin 21. yüzyılda sahip olması gereken yeterliliklere ilişkin öğretmen adaylarının görüşleri incelenmiştir. Araştırma sonucunda Türkçe öğretmen adaylarının görüşlerinden elde edilen veriler temel yeterlilikler ve temel değerler olarak iki ana tema altında toplanırken temel yeterlilikler; kişisel yeterlilikler ve özel alan yeterlilikleri olmak üzere iki alt ayrı alt tema olarak değerlendirilmiştir.

Araştırma sonucunda Türkçe öğretmenlerinin sahip olması gereken temel yeterliliklerden özel alan yeterlilikleri içerisinde ilk sırada teknolojinin derste etkin kullanımı yer almaktadır. Bu bulgudan hareketle Türkçe öğretmeni adaylarının teknolojinin kullanımına ilişkin farkındalıklarının yüksek olduğu söylenebilir. Benzer şekilde Erdoğan ve Eker (2020) tarafından Türkçe öğretmeni adaylarının 21. yüzyll algılarına ilişkin çalışmasında katılımcıların bilgi, medya ve teknoloji becerilerine ilişkin yeterlilik algılarının yüksek olduğu tespit edilmiştir. Türkçe Dersi Öğretim Programında (2019) da ayrı bir alan olarak yer alan "dijital yetkinlik" ve "bilim/teknolojide temel yetkinlikler" başlı̆ı̆ında da bu konunun önemine vurgu yapılmaktadır. Teknolojinin bilginin erişimi ve insan becerilerinde meydana getirdiği bu farklılaşma öğretim sürecine etkin bir şekilde adapte edilmeli ve dijital uyumsuzlukla karşılaşmadan eğitimin hayatla bütünleşmesi gereklidir (Atal ve Usluel, 2011). Nitekim kâğıt ve kalem devri için tasarlanan müfredatlar dijital çağın araçlarının gerisinde kalmış ve çağın dijital diline tek başına cevap verecek konumdan uzaklaşmıştır (Resnick, 2002). Uluslararası düzeydeki anlayış da kaliteli eğitimin, çağdaş eğitim teknolojileriyle yapılandırılması gerektiği fikrini desteklemektedir (Hızal, 1992). 21. Yüzyll Becerileri Ortaklık Organizasyonu tarafından teknolojiyle eğitimi bütünleştirmek amaciyla yayınlanan "21. Yüzyll Öğrencisi İçin Standartlar” adlı raporda da eğitim sisteminin tüm bileşenlerinin çağın şartlarına uygun becerilerle eğitimde aktif kullanımının sağlanmasına vurgu yapılmaktadır. Ülkemizde FATİH Projesi ile başlayan bu dönüşümle çağın şartlarına ve günümüz öğrencilerinin niteliklerine uygun olarak bilişim teknolojilerinin eğitimde aktif olarak kullanımı amaçlanmaktadır (Kamacı ve Durukan, 2012).

Teknolojinin eğitimle bütünleşmesi için öğretmenler günümüz teknolojilerini ve alan bilgilerini öğrencinin kavrayabileceği şekilde birleştirebilmelidirler (Mishra ve Koehler, 2006; Michalski, Hodges ve Banister, 2005; Seferoğlu, 2013). Yani öğretmenler dijital araçların dillerini kavramış olmalı ve bunları pedagojik alan bilgileriyle bütünleştirebilmelidirler (Anderson, 2008; Gülcü, Solak, Aydın ve Koçak, 2013; Yaman, Demirtaş ve Aydemir, 2013; Yurdakul, 2011). Bunun için de teknolojik becerilerini ders süreciyle bütünleştirilmesini sağlayacak örnek uygulamalarla örülü bir sistem oluşturulmalıdır (Soong ve Tan, 2010). Öğretmenlerin teknolojik yetkinlikleri ve mesleki öz yeterlilikleri arasındaki doğrusal ilişkiye rağmen (Demircioğlu, 2008; Ekici, Ekici ve Kara, 2012) yapılan araştırmalar, öğretmen ve öğretmen adaylarının teknolojik becerileri etkin ve yerli yerinde kullanmaya ilişkin yeterli birikime sahip olmadığı yönündedir (Gülbahar, 2008; İşman, 2002; İmer, 2000; Namlu ve Ceyhan, 2002; Kocasaraç, 2003; Stephens, 2005). Türkçe öğretmenleri ve öğretmen adayları da derslerde teknolojinin kullanımı noktasında benzer durumdadır (Atlı ve diğerleri, 2007; Duman ve Demir, 2004; Yaman ve Beyreli, 2006). Bu gerekçelerden hareketle öğretmenlerin bu yeterlilikleri edinebilmeleri için eğitim fakültelerinde, dijital pedagojik yeterlilikleri en üst düzeyde geliştirecek yöntem ve tekniklerin öğretimi ve uygulamasına olanak sunulmalıdır (Akpınar, 2003). Eğitim fakülteleri dijital araçların dilini çözümlemiş yetkinlikte öğretmenler yetiştirmek için gerek ders içeriklerini gerekse teknolojik alt yapılarını buna göre dizayn etmelidir. Türkçe öğretimi alanında değerlendirildiğinde bu araçların öğrenme alanlarına (dinleme-okuma-konuşma-yazma) göre kullanımlarına ilişkin gerekli yeterliliklerin edinilmesine ilişkin alt yapılar oluşturulmalıdır. Pedagojik

\footnotetext{
\begin{tabular}{r|l} 
Adres & $\begin{array}{l}\text { Address } \\
\text { RumeliDE Dil ve Edebiyat Araşttrmaları Dergisi }\end{array}$ \\
RumeliDE Journal of Language and Literature Studies
\end{tabular} Osmanağa Mahallesi, Mürver Çiçeği Sokak, No:14/8 Osmanağa Mahallesi, Mürver Çiçeği Sokak, No:14/8 Kadıköy - İSTANBUL / TÜRKIYE 34714 Kadıköy - ISTANBUL / TURKEY 34714 e-posta: editor@rumelide.com e-mail: editor@rumelide.com, tel: +90 505 7958124, +90 2167730616 phone: +90 505 7958124, +90 2167730616
} 
alan bilgisinin, dijital bileşenlerle örtüşmesi için her öğrenme alanında ekipler oluşturulup bu araçların derslerde etkin bir şekilde kullanımı noktasında ortak hareket edilmelidir. Böylelikle öğretim elemanlarının dijital araçları öğrenme alanlarına uyarlayabilmeleri noktasında daha kaliteli bir eğitim verilmesine katkı sağlanacaktır. Ayrıca bu yeterliliklerin edinilmesi için dilsel, işitsel ve görsel uyaranların birlikte kullanılabildiği çok uyaranlı öğrenme ortamlarının oluşturulması gerekmektedir.

Araştırma sonucunda Türkçe öğretmenlerinin sahip olması gereken özel alan yeterlilikleri arasında Türkçeyi ve temel dil becerilerini etkin kullanım, sınıf içerisinde etkili iletişim becerisine sahip olma, öğretim sürecini planlama ve zamanı aktif kullanım, meslektaşlarıyla iş birliği ve disiplinler arası bakış açısına sahip olma sırasıyla en sık tekrarlanan görüşlerdir. Bu yeterlilikler incelendiğinde hepsinin de 21. yüzyılda öne çıkan beceriler olduğu ve öğretmen eğitiminde çağın ihtiyaçlarını ön plana çıkaran bu hususlara ağırlık verilmesi gerektiği söylenebilir. Benzer şekilde Coşkun, Özer ve Tiryaki (2010)'nin Türkçe öğretmeni adaylarının özel alan yeterlilik algılarının belirlendiği çalışmada, en yüksek yeterlilik algısının "dilsel becerileri geliştirme" olduğu en düşük yeterlilik algısının "okul, aile ve toplumla iş birliği yapma” alanında olduğu tespit edilmiştir. Bu araştırmada Türkçe öğretmen adaylarının görüşleri içerisinde ön plana çıan yeterliliğin etkili iletişim olması bu yeterliliğin ana dili eğitiminin verildiği Türkçe öğretiminde etkin bir şekilde kullanımı amaçlamaktadır. Eğitim kişilerarası bir etkileşim ve iletişim süreci, öğrenme-öğretme ortamı bir iletişim ortamı, öğrenme de bir iletişim ürünü olarak nitelendirilmektedir (İmre, 2000; Nacar ve Tümkaya, 2011). Beraberinde dil öğretiminde de bireye doğru, açık ve etkili iletişimi sağlayacak becerilerin kazandırılması amaçlanır (MEB, 2019). Öğretmenlerin temel yeterlilikleri arasında öğrencilere model olabilme, rehberlik ve etkili iletişim becerilerine sahip olma saylabilir (Oğuz, 2009; Semerci, 2004). İletişim becerileri, kişilerarası ilişkileri düzenleyen sosyal bir beceri olmakla birlikte (Owen ve Bugay, 2014; Ceyhan, 2006) öğretim sürecinin tüm parçalarına verilen ad olan sınıf yönetimi de temelde sınıf içi iletişim süreci olarak tanımlanmaktadır (Erdem, Erdem, Pala, 2013). Öğretmenin sahip olduğu iletişim becerileri ise bu süreci doğrudan etkilemektedir (Pehlivan, 2005). Bu becerileri gelişmiş öğretmenlerin çevreleriyle ve kendileriyle ilişkilerinde özgüvenleri daha yüksek olmakla birlikte sosyal ve etkileşime açık yapılarıyla da mesleğe yönelik olumlu tutuma sahip olmalarına katkı sağlamaktadır (Tunçeli, 2013). Öğretmenlik mesleğine ilişkin tutumla iletişim becerileri arasında pozitif yönde anlamlı ilişki (Tümkaya, 2011; Yeşil, 2010) iletişim beceri düzeyinin artışıyla öğretmenlik mesleğine verilen değerdeki artış da öğrenmeöğretme sürecini doğrudan etkilemektedir (Tunçeli, 2013). Bu çalışmalardan hareketle Türkçe öğretmenlerinin gelişimi için sınıf içi ve fakülte içi iletişimin geliştirilmesi için grup çalışmalarına ağırlık verilmesi gerektiği söylenebilir.

Türkçe öğretmeni adaylarının özel alan yeterliliklerine ilişkin diğer görüşleri incelendiğinde; öğretim sürecini planlama, yaratıcı materyaller hazırlayabilme, farklı ve yeni yöntem ve tekniklerin kullanımı, zamanı aktif kullanım ön plana çıkmaktadır. Erdoğan ve Eker (2020)'in araştırmasında ise yaşam ve kariyer becerilerine ilişkin algılarının orta seviyede olduğu tespit edilmiştir. Anılan ve Kılıç (2013)'ın Türkçe öğretmenlerinin yeterliliklerine ilişkin çalışmasında öğretmen adaylarının okuma-yazma öğretimi, dilbilgisi konularının sezdirilerek öğretilmesi, dikkat çekme, etkinlik örneklerinin bulunmaması, ölçme ve değerlendirme aşamasında zorlandıkları tespit edilmiştir. Alan yazında Türkçe öğretmenlerine ilişkin araştırmalarda ise alan bilgisi ve alan bilgisi öz yeterlilik inançları açısından kendilerini yeterli gördükleri tespit edilmiştir (İskender, Yiğit ve Bektaş, 2015; Maltepe, 2011). Ancak Türkçe öğretmenleri ve öğretmen adaylarının alan bilgisi noktasında yeterli düzeyde olmadıkları yönünde sonuçlar da mevcuttur (Çer, 2017; Saracaloğlu, Karasakaloğlu ve Gencel, 2010; Şengül, 2012). $\mathrm{Bu}$ araştırmada Türkçe öğretmeni adayları, Türkçe öğretmenlerinin derslerinde farklı ve yeni yöntem ve teknikleri kullanmaları gerektiğini belirtmişlerdir. Çer (2017) ise Türkçe öğretmenlerinin en çok

\begin{tabular}{r|l} 
Adres & Address \\
RumeliDE Dil ve Edebiyat Arasturmalari Dergisi & RumeliDE
\end{tabular}

Osmanağa Mahallesi, Mürver Çiçeği Sokak, No:14/8 Osmanağa Mahallesi, Mürver Çiçeği Sokak, No:14/8

Kadıköy - İSTANBUL / TÜRKIYE 34714 Kadıköy - ISTANBUL / TURKEY 34714

e-posta: editor@rumelide.com

e-mail: editor@rumelide.com

tel: +90 505 7958124, +90 216773 o 616 phone: +90 505 7958124, +90 2167730616 
anlatım yöntemi ile soru-cevap yönteminin tercih ettiklerini belirlenmiştir. Bu bulgulardan hareketle Türkçe öğretmenlerinin özel alan yeterliliklerinin gelişimi için yeni ve farklı tekniklerin gelişimine olanak sağlayacak çalışmalara ağırlık verilmesi gerektiği görülmektedir. Özkan ve Şahbaz (2011)'ın Türkçe öğretmeni adaylarının alan derslerinin işlevselliğini incelediği araştırmasında alan bilgisi derslerinin işlevsel olmayıp yüzeysel olarak verildiği, öğretim elemanlarının yetersizlikleri, derslerin edebiyat ağırlıklı olup araç-gereç kullanımının yetersiz oluşu ve teknolojiden yeterince yararlanılmaması, uygulamalı derslerin ve bunlara ilişkin ortamların yetersiz oluşu başlıca sorunlardır. $\mathrm{Bu}$ sonuçlar bütün olarak değerlendirildiğinde özel alan yeterliliklerinin gelişimine daha fazla zaman ayrılmalı, bu yeterliliklerle ilgili yenilikçi ve farklı uygulamalara olanak sunacak şekilde ders içeriklerinin sürekli güncellenmesi gerektiği söylenebilir. Türkçe dersi beceri temelli bir ders olması sebebiyle dinleme, okuma, konuşma ve yazma öğrenme alanlarına ilişkin dersler uygulamalı olarak okullarda yapılmalıdır. Türkçe öğretmen adaylarının bu beklentileri doğrultusunda özel alan yeterliliklerinin gelişimine katkı sağlayacak seminer, proje gibi çalışmalarla bu gelişim süreci desteklenmelidir. Ayrıca öğretmen adayları hizmet öncesinde farklı platformlarda kendilerini ifade etmelerine olanak sunacak çalışmalarla desteklenmeli, öğretmenlik sürecinde de yaşadıkları çevrede yaygın etki oluşturacak çalışmalar yapacak duyarlılık ve yetkinlik kazandırılmalıdır.

Öğretmenin sınıf içi iletişimde gerek öğrencinin gelişimi ve gerekse bilginin paylaşımında öğrenme yaşantılarını sunacak ortak bir iletişim diliyle model olması gerekmektedir. Bu modellemede cinsiyete dayalı farklılıklar da gözlenmekte olup bu araştırma sonucunda kadın öğretmen adaylarının "yaratıcı materyaller hazırlayabilme", "bireysel farklılıkları dikkate alma" ve "işini sevme" yönünde belirttikleri kodlarla erkek öğretmenlerden ayrılmaktadırlar. Bu durumda kadın öğretmen adaylarında özel alan yeterlilikleri olarak duyguyu ve ayrıntıları idrak etmeyi karşlayan yeterliliklerin ön plana çıktığı söylenebilir. Ayrıca kadın ve erkek öğretmen adayları arasında en belirgin farklılıkların disiplinler arası bakış açısına sahip olma ve yenilikleri takip edebilmelerine ilişkin görüşleridir. Farklı disiplinlerdeki kavramların bütünleştirilmesi olan disiplinler arası yaklaşım çok disiplinli yaklaşım (multidisciplinary), çapraz disiplinli yaklaşım (crossdisciplinary) ve disiplinler ötesi yaklaşım (transdisciplinary) olarak gelişim göstermiştir (Aktan 2009). Yüksek öğretimde değişimi etkileyen ve yönlendiren sürükleyici dinamikler arasında değerlendirilen "bilgi toplumu", "yeni temel teknolojiler", "internet devrimi” kavramlarıdır. Aktan (2009)'a göre yaşam boyu öğrenim, uzaktan eğitim, online eğitim, e-öğrenme, disiplinler arası eğitim-çok disiplinli eğitim-öğretim kavramlarıyla açıklanmaktadır. Bu araştırmada Türkçe öğretmen adaylarının 21. yüzyıl becerileri noktasındaki bakış açılarının bu dönemin en önemli kavramlarından biri olan disiplinler ötesi bakış açısına doğru taşıyan bir farkındalığa sahip oldukları söylenebilir. Bu bulgu Türkçe öğretiminde eğitim fakültelerinin güncelliğini koruyabilmesi için disiplinler arası yaklaşımları ön plana çıkaran eğitim ve öğretim faaliyetlerinin yanı sıra disiplinler ötesi yaklaşımı destekleyen çalışmalarla da desteklemesi gerektiğini göstermektedir. Bu çoğulcu bakış açısındaki farklılık ve bunun oluşturduğu farkındalık da eğitimin nihai amacı olan kendini bilme sürecinin bütünsel olarak algllamasına önemli katkılar sağlayacağı söylenebilir.

Yükseköğretimde değişimi yönlendiren bu sürükleyici güçlerin etkin kullanımı bilginin elde edilmesi ve örgütlenmesinde çağdaş eğitim yöntem ve araçlarına ilişkin becerilere sahip öğretmenlerle gerçekleşecektir (D’Angelo ve Erbil, 2012). Öğretmenlerin özel alan yeterliliklerini destekleyen en önemli iskelet yapı, öğretmenin sahip olduğu yeterliliklerdir. Bu araştırmada kadın öğretmen adayları açısından kişisel yeterlilikler "yenilikçilik", "öğrenmekten zevk alma”, "yaratıcılık”, "yaşam boyu öğrenmeyi benimseme", "kendini tanıma" ve "eleştirel düşünebilme" erkek öğretmen adayları açısından ise "eleştirel düşünebilme", "merak", "yaratıcılık” ve "yenilikçilik" ön plana çıkan görüşlerdir.

\footnotetext{
Adres $\mid$ Address

RumeliDE Dil ve Edebiyat Araşttrmaları Dergisi $\quad$ RumeliDE Journal of Language and Literature Studies Osmanağa Mahallesi, Mürver Çiçeği Sokak, No:14/8 Osmanağa Mahallesi, Mürver Çiçeği Sokak, No:14/8 Kadıköy - İSTANBUL / TÜRKIYE 34714 Kadıköy - ISTANBUL / TURKEY 34714 e-posta: editor@rumelide.com e-mail: editor@rumelide.com tel: +90 505 7958124, +90 2167730616 phone: +90 505 7958124, +90 2167730616
} 
Bu sonuçlar bütün olarak değerlendirildiğinde "yenilikçilik", "yaratıcıllk", "eleştirel düşünebilme”, "öğrenmekten zevk alma” ve "kendini tanıma" olarak en çok belirtilen görüşlerdir. Bu becerilerin hepsinin 21. yüzyll temel becerileri içerisinde yer aldığı bu bulgu da Türkçe öğretmeni adaylarının bu yüzyılın becerilerini ve niteliklerinin farkında olduklarını göstermektedir. Nitekim Erdoğan ve Eker (2020), Türkçe öğretmeni adaylarının 21. yüzyll becerileri ve yaşam boyu öğrenme becerileri arasında pozitif, anlamlı ve orta düzeyde ilişki olduğunu ve bu iki değişkenin birbirinin anlamlı bir yordayıcısı olduğunu tespit etmiştir.

Küreselleşme ortamında eğitimin gelişebilmesi için değişen taleplere cevap vermesinin yanı sıra küresel düzeyde başarı elde edebilmek için yaratıcı yeniliklere de ihtiyaç vardır (Burkus, 2014'ten aktaran Özgenel ve Çetin, 2017). Bu istenilen yeniliklerin açığa çıkması yaratıcı bireylerle sağlanacaktır (Ergün, 2007). Erdoğan ve Eker (2020)'in araştırmasında Türkçe öğretmen adaylarının yeni bilgi ve beceri kazanmak için zaman ayırma, firsatlar oluşturma açısından yeterli düzeyde oldukları tespit edilmiştir. Bu araştırmada kadın öğretmen adayları için ilk sırada yenilikçilik ve yaratıcılık erkekler için de eleştirel düşünebilme ve merak kodlarının daha ön planda oluşu Türkçe öğretimi açısından fırsata dönüştürülebilmelidir. Alan yazında yapılan araştırmalarda kadınların eleştirel düşünme becerilerinin erkeklere oranla daha gelişmiş olduğunu gösteren araştırma bulgularına da rastlanmaktadır (Gilstrap ve Dupree, 2008; Yıldırım, 2005; Gülveren, 2007). Derinlemesine ve nesnel düşünmeyi kapsamayan en gelişmiş düşünme biçimlerinden olan eleştirel düşünmeye ilişkin bu farklılık (İpşiroğlu, 2002), kadın ve erkeklerin bilimsel düşünme becerilerinin yordayıcılarının farklı değişkenler olması (Gündoğdu, 2001) ya da kadın ve erkek beyninin farklı sistemler üzerinden çalışmasıyla açıklanabilir (Ying-shan ve Yan, 2009). Bu sonuçlardan hareketle Türkçe öğretmenlerinin sahip olması gereken 21. yüzyll yeterliliklerinin tanımlanmasında cinsiyete dayalı farklılıkların dikkate alınması bununla birlikte yaratıcılığı destekleyen çalışmaların da ön plana çıkması gerektiği görülmektedir. Türkçe Öğretmenliği Lisans Programında (2018), Meslek Bilgisi Seçmeli Dersler kategorisinde yer alan "Eleştirel ve Analitik Düşünme" dersi, Alan Eğitimi Seçmeli Dersler kategorisinde yer alan "Eleştirel Okuma" ve "Yaratıcı Yazma" dersleri vasıtasıyla eleştirel düşünme ve yaratıcı düşünme becerilerinin geliştirilmesi amaçlanmaktadır. Ancak mevcut uygulamalar çerçevesinde "Yaratıcı Yazma" ya da "Eleştirel Okuma" derslerinin içeriğinin yoğunluğu sebebiyle bu derslerin de ayrı kategorilerde değerlendirilmesi "Eleştirel Düşünme" ve "Yaratıcı Düşünme" derslerinin programa eklenmesi gerektiği söylenebilir. Özellikle yaratıcı düşünmenin dil becerileri açısından gelişimine olanak sağlayacak üst düzey bir okuma yöntemi olan "Yaratıcı Okuma" dersinin de lisans programına dahil edilmesinin öğretmen kalitesinin arttırılması açısından olumlu katkılar sağlayacağı düşünülmektedir.

Araştırmada sonucunda kişisel yeterlilikler açısından "kendini güncelleyebilme", "esnek ve uyumlu olma", "önyargısız olma" ve "stresle başa çıabilme" kodlarına ilişkin sadece kadın öğretmen adaylarının görüş bildirdiği belirlenmiş̧ir. Bu bulgulardan hareketle kadın öğretmen adaylarının çok boyutlu düşünme ve olaylara daha farklı açılardan yaklaşma becerileri daha ön plana çıkmaktadır. Facione, Giancarlo, Facione ve Gainen (1995)'ın üniversite öğrencileriyle gerçekleştirdiği çalışmada kızların açı fikirli olmaya ve bilişsel olgunluğa erkeklerden daha eğilimli olduklarını, erkeklerin ise çözümleyici (analitik) düşünme eğilimlerinin kızlardan daha yüksek olduğunu tespit edilmiştir. Eğitim sisteminin bireyselliğe doğru evrildiği günümüzde Türkçe öğretmen adaylarının eğitimleri sürecinde bu farklılıkların dikkate alınması mevcut yeteneklerinin gelişimi açısından pozitif katkılar sağlayabilir.

Türkçe öğretmenlerinin sahip olması gereken değerlere ilişkin bulgular incelendiğinde kadın öğretmen adayları açısından "sevgi", "vatanseverlik ve millî değerlere bağlllık", "saygı" ve "hoşgörü"; erkek 
öğretmen adayları açısından ise "saygı", "sevgi”, "vatanseverlik ve milli değerlere bağlılık” ön plana çlkmaktadır. Samimiyet ve yardımseverlik değerlerinin sadece kadın öğretmen adayları tarafından ifade edildiğine ilişkin bulgulardan hareketle kadınlardaki merhamet ve ince duyuşun daha ön plana çıktığı söylenebilir. $\mathrm{Bu}$ değerlere ilişkin bulgular bütün olarak yorumlandığında ise Türkçe öğretmenlerinin milli ve evrensel değerlere duyarlı bir kavrayışlarının olduğu söylenebilir. Nitekim Türkçe Dersi Öğretim Programındaki (MEB, 2019) "Eğitim sistemimizin temel amacı değerlerimiz ve yetkinliklerle bütünleşmiş bilgi, beceri ve davranışlara sahip bireyler yetiştirmektir” ifadesiyle programın değerlere ilişkin perspektifi ortaya konulmuştur. Kılınç ve Akyol (2009)'a göre eğitimin temel hedefi insanın kendini tanıması ve gerçekleştirmesidir. Değerlerin nihai hedefi ise insanın mutlu olmasını sağlamaktır. İnsanın kendini gerçekleştirdiği oranda mutlu olacağı fikrinden hareketle değerler eğitim sisteminde etkin role sahip olduğu görülmektedir (Tarhan, 2011). Eğitim hayatıyla birlikte farklı açılımlarla gelişimine devam eden değerler eğitimi bireyin biricikliğini koruyacak nitelikte özgün yaklaşımlarla desteklenmelidir. Bu çerçevede değerlerin öğretilmesi, içselleştirilmesi ve aktarılması için bilinçli bir girişim olan değerler eğitiminin (Keskin, 2008) gelişimsel yapısı sebebiyle eğitim ve öğretimin her kademesinde olduğu gibi öğretmen eğitimi sürecinde de devam etmelidir. Soyut kültürel bilgiler olan değerlerin bireyin eğitimini sürecindeki etkisinden hareketle bir kültür ve beceri dersi olan Türkçe öğretiminde de değer eğitimi ön plana çıarılarak bilinçli bir politikayla yürütülmelidir. Bu ders, Türkçe Dersi Lisans Programında (2018) Meslek Bilgisi Seçmeli Dersler kategorisinde seçmeli ders olarak "Karakter ve Değer Eğitimi” adıyla yerini almıştır. Bu olumlu bir gelişme olarak kaydedilmekle birlikte bu dersin seçmeli bir ders olması sebebiyle ancak dersi seçen öğrencilerin gerekli eğitimi alabileceklerinden hareketle bu gelişmenin yeterli olmadığı söylenebilir. Türkçe öğretmenlerinin değerleri inşa edişindeki rollerinin yanı sıra değerlerin asıl gayesi olan insanın kendindeki gizil güçleri keşfederek kendini gerçekleştirmesidir. Öğretmenlerin hizmet öncesi eğitimlerinde milli değerlerden evrensel değerlere uzanan geniş bir yelpazede etik ve estetik değerlerle zenginleştirilmiş özgün bireylerin yetiştirilmesine katkı sağlanması için öncelikle bu değerleri özümsemeleri sağlanmalıdır. Bu gerekçelerle bu dersin zorunlu bir derse dönüştürülmesinin Türkçe öğretimi açısından olumlu katkılar sağlayacağı düşünülmektedir. Bununla birlikte bu ders uygulamalı ve işlevsel etkinliklerle de yapılandırılmalıdır. Bu süreç, kök değerlerin evrensel değerlerle örüldüğü ve çağın şartlarına göre güncellenecek bir perspektifle yürütülmelidir. Ayrıca Türkçe öğretmenlerinin milli kültürümüzü ve değerlerimizi aktarmadaki rollerini aktif olarak gerçekleştirebilmeleri için Türkçe Öğretmenliği Programında yapılacak yeniliklerde Türk kültürünün kadim değerlerini tanıtıcı derslere yer verilmesi de süreci daha dinamik kllacaktır. Bunun için geçmişten günümüze kültürümüzün öncü karakterlerinin tanıtıldığı derslerle kültürümüzün rol modellerinin üstlendiği işlevler ve bunların kültürümüze katkıları planlı ve sistematik bir şekilde tanıtılmasıyla öğretmen adaylarının gelişiminde olumlu etkiler oluşturacağı düşünülmektedir.

Araştırmadan elde edilen sonuçlardan hareketle Türkçe öğretmeni adaylarının 21. yüzyılda yeterlilik ve değerlere ilişkin görüşlerinin ortaya koyduğu öğretmen profilinin çağdaş normlarla örtüştüğü söylenebilir. Özel alan yeterlilikleri açısından dijital çă̆ araçların ve Türkçenin etkin kullanımı; kişisel yeterlilikler açısından yaratıcılık ve yenilikçilik; değerler açısından ise sevgi ve saygıya dayalı bir dünya görüşünün ön plana çıktı̆̆g görülmektedir. Özetle bu araştırmada dijital çağın dilini kavramış ve bu dili sevgiyle örülü yenilikçi ve yaratıcı bir üslupla ortaya koyabilen bir Türkçe öğretmeni modeli betimlenmiştir.

RumeliDE Dil ve Edebiyat Araştırmaları Dergisi Osmanağa Mahallesi, Mürver Çiçeği Sokak, No:14/8 Kadıköy - İSTANBUL / TÜRKIYE 34714 e-posta: editor@rumelide.com tel: +90 $5057958124,+902167730616$
Address

RumeliDE Journal of Language and Literature Studies

Osmanağa Mahallesi, Mürver Çiçeği Sokak, No:14/8

Kadıköy - ISTANBUL / TURKEY 34714

e-mail: editor@rumelide.com,

phone: +90 5057958124 , +90 216773 o 616 


\section{Öneriler}

1. Eğitim fakültelerinde Türkçe öğretiminde kullanılabilecek dijital araçların, öğrenme alanlarına göre sınıflandırılarak kullanımını sağlayacak çok uyaranlı sınıfların ve sistemlerin kurulması gereklidir.

2. Eğitim fakülteleri tekno-pedagojik alan bilgisi noktasında alt yapılarını yenileyerek gerek öğretim elemanlarının gerekse öğretmen adaylarının kendilerini sürekli yenileyebileceği sanal platformlarla bu yenilikleri sürekli takip edebilecekleri sistemler oluşturabilir. Bu sanal gelişim ortamları sadece öğretmen adayları değil mezun olanları da kapsayıcı dinamik yapıdan oluşmalıdır. Böylelikle mezun olan öğretmenler için de eğitimde süreklilik sağlanarak hayat boyu öğrenme becerilerinin gelişimine katkı sağlanabilmelidir.

3. Eğitim fakültelerinin öneminden hareketle il bazında yapılacak uygulamalarla sanal platformların erişilebilirlikteki kolaylığından yararlanarak bu platformları illerdeki Türkçe öğretmenlerinin de erişimine olanak sunarak yaygın etki arttırılabilir.

4. Öğretmenlerin kişisel gelişimini çağın şartlarıyla destekleyecek özgünlükte proje, seminer gibi çalışmaların yanı sıra yaratıcılık ve yenilikçiliğin gelişimine olanak sunabilecek disiplinler arası çalışmalar yapılabilir.

5. Değerlerin gelişimi için yenilenen lisans programındaki Karakter ve Değer Eğitimi dersi uygulamalı ve zorunlu bir derse dönüştürülerek Türk kültürünün kadim değerlerinin tanıtılması ve içselleştirilmesine olanak sağlanabilir.

6. Eğitim fakültelerinde ilgili bölümlerin öğretmenleri ve öğretmen adaylarının beklentilerini dile getirebilecekleri sanal platformlar oluşturularak değişen beklenti ve anlayışlar sürekli takip edilmeli böylelikle eğitimin dinamik bir şekilde işleyişine katkı sağlanabilmelidir. Bu platformlara öğretim elemanları, veliler, eğitim yöneticileri gibi bu yapının diğer paydaşları da dahil edilerek sürecin panoromik bakış açısıyla değerlendirilmesi sağlanmalıdır.

\section{Kaynakça}

AASL (American Association of School Librarians). (2009). Standards for the 21st Century Learner. [Online]: http://www.ala.org/aasl/standards-guidelines/learning-standards, Erişim Tarihi: 15. 01. 2021.

Aktan, C. C. (2009). Yüksek öğretimde değişim: global trendler ve yeni paradigmalar. Organizasyon ve Yönetim Bilimleri Dergisi, 1(2), 39-48.

American Association of School Librarians (AASL). [Online]: http://www.ala.org/aasl/standards. Erişim Tarihi: 12. 09. 2020.

Akpınar, B. (2009). İlköğretim 1-5. sınıflar Türkçe öğretim programları görsel okuma ve sunu öğrenme alanının değerlendirilmesi. Ĕ̆itim ve Bilim, 34(154), 37-49.

Aktan C. (2009). Yükseköğretimde değişim: Global trendler ve yeni paradigmalar. Yaşar Üniversitesi Yayını, İzmir.

Altınpulluk, H., \& Yıldırım, Y. (2020). 2010-2019 yılları arasında yayınlanan 21. yüzyll becerileri araştırmalarının incelenmesi. Anadolu Journal of Educational Sciences International, 11(1), 438-461.

Anderson, T. (2008). Towards a theory of online learning, in Anderson, T. (Ed.) Theory and practice of online learning, (pp. 45-74). AU Press.

Adres Address

RumeliDE Dil ve Edebiyat Araştırmaları Dergisi $\quad$ RumeliDE Journal of Language and Literature Studies

Osmanağa Mahallesi, Mürver Çiçeği Sokak, No:14/8 Osmanağa Mahallesi, Mürver Çiçeği Sokak, No:14/8

Kadıköy - İSTANBUL / TÜRKIYE 34714 Kadıköy - ISTANBUL / TURKEY 34714

e-posta: editor@rumelide.com

e-mail: editor@rumelide.com,

tel: +90 505 7958124, +90 216773 o 616 phone: +90 505 7958124, +90 2167730616 
Atal, D., \& Usluel, Y. (2011). İlk öğretim öğrencilerinin okul içinde ve dışında teknoloji kullanımları. Hacettepe Üniversitesi Ĕ̈itim Fakültesi Dergisi, 41, 24-35.

Atlı, Ş., Aksüt, M., Atar, G., \& Yıldız, N. (2007). Türkçe öğretmen adaylarının bilişim teknolojilerine yaklaşımı. Akademik Bilişim Konferansı Bildirileri 31 Ocak-2 Şubat 2007 Dumlupınar Üniversitesi, Kütahya.

Cavin, R. (2007). Technological pedagogical content knowledge in pre-service teachers through micro teaching lesson study. [Online]: https://scholar.google.com.tr/scholar?hl=tr\&q=Technological+Pedagogical+Content+Knowled ge+in+PreService+Teachers+Through+Microteaching+Lesson+Study\%E2\%8o\%9D\&btnG=\&lr =. Erişim Tarihi: 15. 01. 2021.

Ceyhan, A. A. (2006) An investigation of adjustement levels of Turkish university students with respect to perceived communication skill levels. Social Behaviour and Personality, 34(4), 367379.

Cohen, L., Manion, L., \& Morrison, K. (2011). Research method in education. London: Routledge.

Coşkun, E., Özer, B., \& Tiryaki, E. N. (2010). Türkçe öğretmeni adaylarının özel alan yeterlik algllarının değerlendirilmesi. Dokuz Eylül Üniversitesi Buca Eğitim Fakültesi Dergisi, 27, 123136.

Creswell, J. W. (2012). Educational research. Boston: Pearson Education.

Çelikten, M., Şanal, M., \& Yeni, Y. (2005). Öğretmenlik mesleği ve özellikleri. Erciyes Üniversitesi Sosyal Bilimler Enstitüsü Dergisi, 19(2), 207-237.

Çer, E. (2017). Türkçe öğretmenlerinin "Türkçe öğretimine" yönelik yeterlilikleri. Pamukkale Üniversitesi Sosyal Bilimler Enstitüsü Dergisi, (26), 68-89.

D’Angelo, G., \& Erbil, T. T. (2012). Didaktikten e-didaktiğe, e-öğrenim paradigmalar, modelleri ve teknikleri. LLP-LDV/TOI/o8/IT/500 numaralı Proje ürünü Türkçe Basımı, Türkiye.

Demircioğlu, İ. H. (2008). Etkili öğretmen. İ. H. Demircioğlu (Ed.). Okul deneyimi ve öğretmenlik uygulaması içinde (s. 1-14). Ankara: Anı Yayıncılık.

Demirel, Ö. (2004). Öğretimde planlama ve değerlendirme: Öğretme sanatı. Ankara: Pegem A Yayıncilı.

Duman, B., \& Demir, M. (2004). Tezsiz yüksek lisans Türk dili ve edebiyatı öğretmen adaylarının edebiyat derslerinde bilgisayara dayalı öğretim ve interneti kullanmaya dair görüşleri. Uluslararası Eğitim Teknolojileri Sempozyumu, Bildiriler II, 1081-1087. Sakarya.

EARGED (Eğitimi Araştırma ve Geliştirme Dairesi Başkanlı̆̆ı). (2011). MEB 21. yüzyıl öğrenci profili. Ankara: MEB EARGED. [Online]: https://www.meb.gov.tr/earged/earged/ 21.\%20yy_og_pro.pdf. Erişim Tarihi: 17.06.2020.

Erdem, A., Erdem, M., \& Pala, F. K. (2013). Dil becerilerinin geliştirilmesi için yapılandırmacı karma öğrenme ortamı ölçeği. Ankara Üniversitesi Eğitim Bilimleri Fakültesi Dergisi, 1(46), 365-394.

Erden, M. (2005). Öğretmenlik mesleğine giriş. İstanbul: Alkım Yayınları.

Erdoğan, D., \& Eker, C. (2020). Türkçe öğretmen adaylarının 21. yy becerileri ile yaşam boyu öğrenme eğilimleri arasındaki ilişkinin incelenmesi. Karaelmas Eğitim Bilimleri Dergisi, 8(1), 118-148.

Ergün, E. (2007). İnsan kaynakları yönetiminde kariyer planlama ve bir uygulama. Yayımlanmamış yüksek lisans tezi. Marmara Üniversitesi, Sosyal Bilimler Enstitüsü, İstanbul.

Eskicumalı, A. (2002). Eğitim, öğretim ve öğretmenlik mesleği. Y. Özden (Ed.), Öğretmenlik mesleğine giriş içinde (ss. 2-31). Ankara: Pegem A Yayıncılık.

Erten, P. (2019). Öğretmen adaylarının 21. yüzyıl becerileri yeterlilik algıları ve bu becerilerin kazandırılmasına yönelik görüşleri. Milli Eğitim Dergisi, 49(227), 33-64.

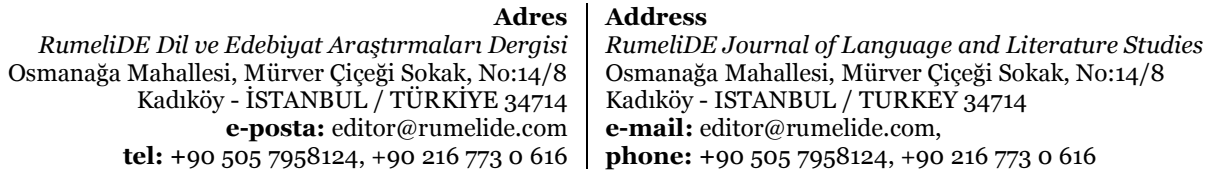

RumeliDE Dil ve Edebiyat Araştırmaları Dergisi Mürver Çiçeği Sokak, No:14/ e-posta: editor@rumelide.com tel: +90 505 7958124, +90 2167730616 
Ekici, E., Ekici, F. T., \& Kara, İ. (2012). Öğretmenlere yönelik bilişim teknolojileri öz-yeterlik algısı ölçeğinin geçerlik ve güvenirlik çalışması. Pamukkale Üniversitesi Eğitim Fakültesi Dergisi, 31(31), 53-65.

Facione, P. A., Giancarlo, C. A., Facione, N. C., \& Gainen, J., (1995). The disposition toward critical thinking. Journal of General Education. 44(1),1-25.

Gelen, İ. (2017). P21-Program ve öğretimde 21. yüzyl beceri çerçeveleri (ABD Uygulamaları). Disiplinlerarası Eğitim Araştırmaları Dergisi, 1(2), 15-29.

Gülbahar, Y. (2008). Improving the technology integration skills of prospective teachers through practice: A case study. The Turkish Online Journal of Educational Technology (TOJET), 7(4), 71-81.

Gülcü, A., Solak, M., Aydın, S., \& Koçak, Ö. (2013). İlköğretimde görev yapan branş öğretmenlerinin eğitimde teknoloji kullanımına ilişkin görüssleri. Electronic Turkish Studies, 8(6), 195-213.

Gültekin, M. (2020). Değişen toplumda eğitim ve öğretmen nitelikleri. Anadolu Üniversitesi Eğitim Bilimleri Enstitüsü Dergisi, 10(1), 654-700.

Gürültü, E., Aslan, M., \& Alcı, B. (2019). Ortaöğretim öğretmenlerinin 21. yüzyll becerileri kullanım yeterlikleri. Hacettepe Üniversitesi Ĕ̆itim Fakültesi Dergisi, 35(4), 780-798.

Gülveren, H. (2007). Eğitim fakültesi öğrencilerinin eleştirel düşünme becerileri ve bu becerileri etkileyen eleştirel düşünme faktörleri. Yayımlanmamış doktora tezi, Dokuz Eylül Üniversitesi Eğitim Bilimleri Enstitüsü, İzmir.

Gündoğdu, H. (2009). Eleştirel düşünme ve eleştirel düşünme öğretimine dair bazı yamllgılar. Celal Bayar Üniversitesi Sosyal Bilimler Dergisi, 7 (1), 57-74.

Gilstrap, D. L., \& Dupree, J. (2008). Assessing learning, critical reflection, and quality educational outcomes: the critical incident questionnaire. College \& Research Libraries, 69(5), 407-426.

İmer, G. (2000). Eğitim fakültelerinde öğretmen adaylarının bilgisayara ve bilgisayarı eğitimde kullanmaya yönelik nitelikleri. Eskişehir Anadolu Üniversitesi Eğitim Fakültesi Yayınları, Eskişehir.

İpşiroğlu, N., \& İpşiroğlu , Z. (2000). Yaratıcı okuma-I. İstanbul: Özyürek Yayınevi.

İpşiroğlu, Z. (2002). Eleştirel düşünme öğretilebilir mi? [Online]: www.felsefeekibi.com. Erişim Tarihi: 20.03.2021.

İskender, H., Yiğit, F., \& Bektaş, R. (2015). Türkçe öğretmenlerinin özel alan yeterliklerine yönelik görüşlerinin çeşitli değişkenler açısından incelenmesi. Uluslararası Türkçe Edebiyat Kültür Ĕ̆itim Dergisi, 4(1), 305-327.

İşman, A. (2002). Sakarya ili öğretmenlerinin eğitim teknolojileri yönündeki yeterlilikleri. The Turkish Online Journal of Educational Technology, 1(1), 72-91.

Kamacı, E., \& Durukan, E. (2012). Araştırma gorevlilerinin eğitimde tablet bilgisayar kullanımına ilişkin görüşleri üzerine nitel bir araştırma (Trabzon örneği). Uluslararası Türkçe Edebiyat Kültür Eğitim Dergisi, 1(3), 203-215.

Keskin, Y. (2008). Türkiye'de sosyal bilgiler öğretim programlarında değerler eğitimi: Tarihsel gelişim, 1998 ve 2004 programlarının etkililiğinin araştırılması. Yayımlanmamış doktora tezi, Marmara Üniversitesi, İstanbul.

Klecker, B. M., Hunt, S., Hunt, D., \& Lackner, K. (2003). Evaluating student teachers' technology use with group support systems and questionnaire. Annual Meeting of the Mid-South Educational Research Association: Biloxi. [Online]: ERIC. Erişim Tarihi: 12. 05. 2020.

Kılınç A., \& Akyol Ş. (2009). İlköğretim 6. Sinff Türkçe ders kitaplarında yer alan sevgi temasının değerler eğitimi açısından İncelenmesi. The First International Congress Of Educational Research, 1-3 Mayıs Çanakkale.

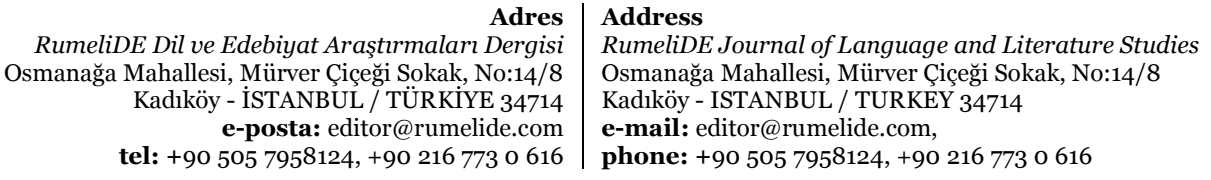

Adres
RumeliDE Dil ve Edebiyat Araşttrmaları Dergisi e-posta: editor@rumelide.com tel: +90 505 7958124, +90 2167730616 
Kocasaraç, H. (2003). Bilgisayarların öğretim alanında kullanımına ilişkin öğretmen yeterlilikleri. The Turkish Online Journal of Educational Technology, 2(3), 77-86.

Maltepe, S. (2011). Türkçe Öğretmeni adaylarının özel alan yeterliklerine sahip olma durumlarına ilişkin görüssleri. E- Journal of New World Sciences Academy, 6(2), 1868-1877.

MEB. (2011). MEB 21. Yüzyıl öğrenci profili. Ankara, Milli Eğitim Basımevi.

MEB. (2017). Öğretmen strateji belgesi 2017-2023. [Online]: http://oygm.meb.gov.tr/meb_iys_dosyalar/2017_06/09140719_Strateji_Belgesi_Resmi_Gaze te_sonrasY_ilan.pdf. Erişim Tarihi: 21. 03. 2020.

MEB. (2019). İlköğretim Türkçe dersi öğretim programı ve kılavuzu (1-8. Sinıflar). Ankara: MEB Yayınları.

MEB (2006). Öğretmenlik mesleği genel yeterlikleri. [Online]: http://www.meb.gov.tr/. Erişim Tarihi: 17. 10. 2020.

MEB (2008). Öğretmen yeterlikleri öğretmenlik mesleği genel ve özel alan yeterlikleri. [Online]: http://www.meb.gov.tr/. Erişim Tarihi: 17. 10. 2020.

Michalski, P., Hodges D., \& Banister S. (2005). Digital storytelling in the middle childhood special education classroom: A teacher's story of adaptations. Teaching Exceptional Children Plus, 1(4). [Online]: ERIC. Erişim Tarihi: 17. 10. 2020.

Miles, M. B., \& Huberman, A. M. (1994). Qualitative data analysis: An expanded sourcebook. California: Sage Publications.

Mishra, P., \& Koehler, M. J. (2006). Technological pedagogical content knowledge: a framework for teacher knowledge. Teachers College Record, 108(6), 1017-1054.

Nacar, F. S., \& Tümkaya, S. (2011). Sınıf öğretmenlerinin iletişim ve kişilerarası problem çözme becerilerinin incelenmesi. İlköğretim Online, $10(2), 493-511$.

Niess, M. (2005). Preparing teachers to teach science and mathematics with technology: developing a technology pedagogical content knowledge. Teaching and Teacher Education: An International Journal of Research and Studies, 21(5), 509-523.

Namlu, A.G., \& Ceyhan, E. (2002). Bilgisayar kaygısı (üniversite öğrencileri üzerinde bir çalışma). Eskişehir Anadolu Üniversitesi Yayınları; No: 1353.

Oğuz, A. (2009b). Öğretmen adaylarının sözlü ve yazılı anlatım becerilerine ilişkin öz yeterlik algıları. Elektronik Sosyal Bilimler Dergisi, 30, 18-42.

Orhan Göksün, D. (2016). Öğretmen adaylarmmn 21. yy. öğrenen becerileri ve 21. yy. öğreten becerileri arasındaki ilişki. Yayımlanmamış doktora tezi. Anadolu Üniversitesi Eğitim Bilimleri Enstitüsü, Eskişehir.

Owen, F. K., \& Bugay, A. (2014). İletişim becerileri ölçeğinin geliştirilmesi: geçerlik ve güvenirlik çalışması. Mersin Üniversitesi Eğitim Fakültesi Dergisi, 1o(2), 50-64.

Özgenel, M., \& Çetin, M. (2017). Marmara yaratıcı düşünme eğilimleri ölçeğinin geliştirilmesi: Geçerlik ve güvenirlik çalışması. Marmara Üniversitesi Atatürk Eğitim Fakültesi Eğitim Bilimleri Dergisi, 46(46), 113-132.

Patton, M. Q. (2002). Qualitative research \& evaluation methods (3rd ed.). USA: SAGE Publication.

Partnershipfor 21st Century Skills. (2003). Learning for the 21st century: A reportand mile guide for 21st century skills. Washington, D.C.: Partnership for 21st Century Skills.

Pehlivan, K. B. (2005). Öğretmen adaylarının iletişim becerisi algıları üzerine bir çalışma. İlköğretim Online, 4(2), 17-23.

Resnick, M. (2002). Rethinking learning in the digital age. In the Global Information Technology Report: Readiness for the Networked World, 3, 32-36.

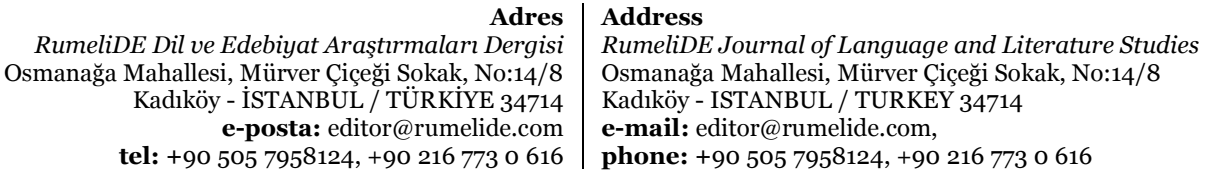

RumeliDE Dil ve Edebiyat Araştırmaları Dergisi Mürver Çiçeği Sokak, No: $14 /$ e-posta: editor@rumelide.com tel: +90 505 7958124, +90 2167730616 
Saracaloğlu, A. S., \& Karasakaloğlu, N. (2011). Türkçe öğretmenlerinin öğretimde kullandıkları yöntem ve tekniklere ilişkin görüşleri. İlköğretim Online, 10(3), 951-960.

Seferoğlu, S. S. (2004). Öğretmen yeterlilikleri ve mesleki gelişim. Bilim ve Aklın Aydınhı̆gnda Eğitim, $58,40-45$.

Semerci, N. (2004). Öğrenci görüşlerine göre sınıf öğretmenliği derslerinin işleyişi. XIII. Ulusal Eğitim Bilimleri Kurultayl, 6-9 Temmuz 2004, Malatya: İnönü Üniversitesi Eğitim Fakültesi.

Stephens P. (2005). A decision support system for computer literacy training at universities. The Journal of Computer Information Systems, 46 (2), 22-35.

Soong, S. K. A., \& Tan, S. C. (2010). Integrating technology into lessons using a TPACK-based design guide. In C.H. Steel, M.J. Keppell, P. Gerbic \& S. Housego (Eds.), Curriculum, technology \& transformation for an unknown future (pp. 919-923). Proceeding sascilite Sydney, Australia.

Şengül, K. (2012). Türkçe öğretmenlerinin özel alan yeterlikleri: Bir durum belirleme çalsşması. Yayımlanmamış yüksek lisans tezi. Firat Üniversitesi Eğitim Bilimleri Enstitüsü, Elazı̆̆.

Tarhan, N. (2011). Güzel İnsan modeli. İstanbul: Timaş Yayınları.

Tunçeli, H. İ. (2013). Öğretmen adaylarının iletişim becerileri ile öğretmenlik mesleğine yönelik tutumları arasındaki ilişkinin incelenmesi (Sakarya Üniversitesi örneği). Pegem Eğitim ve Öğretim Dergisi, 3(3), 51-58.

TTKB (2017). Müfredatta yenileme ve değişiklik çalışmalarımı üzerine. [Online]: https://ttkb.meb.gov.tr/meb_iys_dosyalar/2017_07/18160003_basin_aciklamasiprogram.pdf. Erişim Tarihi: 22. 10. 2020.

TÜSİAD (Türk Sanayicileri ve İş adamları Derneği) (2012). TÜSİAD “21. Yüzyıl Becerileri ve Eğitimin Niteliği" konulu toplantr dizisinin ilkini gerçekleştirdi. [Online]: https://tusiad.org/tr/tum/item/570o-tusiad-21-yuzyil-becerileri-ve-egitimin-niteligi-konulutoplanti-dizisinin-ilkini-gerceklestirdi. Erişim Tarihi: 22. 10. 2020.

Tümkaya, S. (2011). Fen bilimleri öğrencilerinin eleştirel düşünme eğilimleri ve öğrenme stillerinin incelenmesi. Ahi Evran Üniversitesi Eğitim Fakültesi Dergisi, 12(3), 215-234.

TYÇ (2015), Türkiye yeterlilikler çerçevesinin uygulanmasına ilişkin usul ve esaslar hakkında yönetmelik, Bakanlar Kurulunun 2015/8213 sayılı Kararıla 19.11.2015 tarihli ve 29537 sayll Resmi Gazete. [Online]: www.myk.gov.tr/TYC. Erişim Tarihi: 22. 10. 2020.

WEF (World Economic Forum). (2015). New Vision for Education: Fostering Social and Emotional Learning through Technology. [Online]: https://www.weforum.org/reports/ new-vision-foreducation-fostering-social-and-emotional-learning-through-technology. Erişim Tarihi: 21. 10.2020 .

Yaman, H., Demirtaş, T., \& Aydemir, Z. İ. (2013). Türkçe öğretmeni adaylarının dijital pedagojik yeterlilikleri. Electronic Turkish Studies, 8(8), 1407-1419.

Yavuz, M., Özkaral, T., \& Yıldız, D. (2015). The teacher competencies and teacher education in international reports. SDU International Journal of Educational Studies, 2(2), 60-71.

Yeşil, H. (2010). The relationship between candidate teachers' communication skills and their attitudes towards teaching profession. Procedia Social and Behavioral Sciences, 9, 919-922.

Yeşilyurt, E. (2013). Öğretmen adaylarının öğretmen öz-yeterlik algıları. Elektronik Sosyal Bilimler Dergisi, 45(45), 88-104.

Yılmaz, N., \& Altunbaş, S. (2012). Öğretmen adaylarının iletişim becerileri ile sınıf yönetimi becerilerinin incelenmesi. Erzincan Üniversitesi Eğitim Fakültesi Dergisi, 14(1), 183-196.

Ylldırım, A. Ç. (2005). Türkçe ve Türk dili ve edebiyatı öğretmenlerinin eleştirel düşünme becerilerinin incelenmesi. Yayımlanmamış yüksek lisans tezi. Zonguldak Karaelmas Üniversitesi Sosyal Bilimler Enstitüsü, Zonguldak.

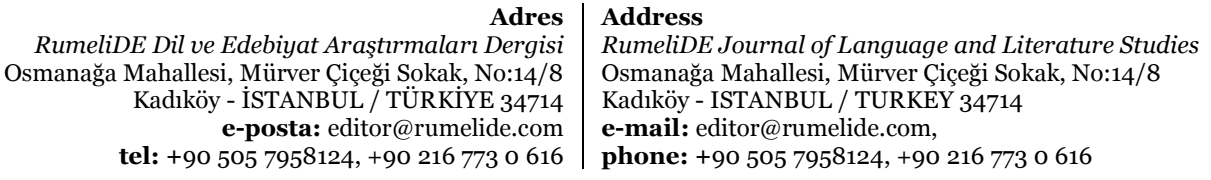

Adres
RumeliDE Dil ve Edebiyat Araşttrmaları Dergisi -posta: editor@rumelide.com tel: +90 $5057958124,+902167730616$

phone: +90 505 7958124, +90 2167730616 
Ying-Shan, M., Yan, Z. (2009). Reseacrh on leadership capabilities of different genders: From View of critical thinking. Management and Service Science, 2009. MASS '09. International Conference on 20-22 September 2009, 1-4.

Yurdakul, I. K. (2011). Öğretmen adaylarının teknopedagojik eğitim yeterliklerinin bilgi ve iletişim teknolojilerini kullanımları açısından incelenmesi. Hacettepe Üniversitesi Eğitim Fakültesi Dergisi, 4O(40), 397-408.

YÖK. (2018). Öğretmen yetiştirme lisans programları. Ankara: YÖK yayını. [Online]: https://www.yok.gov.tr/Documents/Kurumsal/egitim_ogretim_dairesi/Yeni Yetistirme-Lisans Programlari/AA_Sunus_\%20Onsoz_Uygulama_Yonergesi.pdf. Erişim Tarihi: 22. 10. 2020. 